\title{
Influence of intense secondary aerosol formation and long-range transport on aerosol chemistry and properties in the Seoul Metropolitan Area during spring time: results from KORUS-AQ
}

\author{
Hwajin Kim $^{1,2}$, Qi Zhang ${ }^{3,4}$, and Jongbae Heo ${ }^{5}$ \\ ${ }^{1}$ Center for Environment, Health and Welfare Research, Korea Institute of Science and Technology, Seoul, Korea \\ ${ }^{2}$ Department of Energy and Environmental Engineering, University of Science and Technology, Daejeon, Korea \\ ${ }^{3}$ Department of Environmental Science and Engineering, Fudan University, Shanghai, China \\ ${ }^{4}$ Department of Environmental Toxicology, University of California, Davis, CA 95616, USA \\ ${ }^{5}$ Center for Healthy Environment Education \& Research, Graduate School of Public Health, \\ Seoul National University, Seoul, Korea
}

Correspondence: Qi Zhang (dkwzhang@ucdavis.edu)

Received: 11 October 2017 - Discussion started: 8 November 2017

Revised: 3 May 2018 - Accepted: 5 May 2018 - Published: 24 May 2018

\begin{abstract}
Non-refractory submicrometer particulate matter $\left(\mathrm{NR}-\mathrm{PM}_{1}\right)$ was measured in the Seoul Metropolitan Area (SMA), Korea, using an Aerodyne high-resolution timeof-flight aerosol mass spectrometer (HR-ToF-AMS) from 14 April to 15 June 2016, as a part of the Korea-US Air Quality Study (KORUS-AQ) campaign. This was the first highly time-resolved, real-time measurement study of springtime aerosol in SMA and the results reveal valuable insights into the sources and atmospheric processes that contribute to PM pollution in this region.

The average concentration of submicrometer aerosol $\left(\mathrm{PM}_{1}=\mathrm{NR}-\mathrm{PM}_{1}+\right.$ black carbon $\left.(\mathrm{BC})\right)$ was $22.1 \mu \mathrm{g} \mathrm{m}{ }^{-3}$, which was composed of $44 \%$ organics, $20 \%$ sulfate, $17 \%$ nitrate, $12 \%$ ammonium, and $7 \%$ BC. Organics had an average atomic oxygen-to-carbon $(\mathrm{O} / \mathrm{C})$ ratio of 0.49 and an average organic mass-to-carbon (OM/OC) ratio of 1.82 . Four distinct sources of OA were identified via positive matrix factorization (PMF) analysis of the HR-ToF-AMS data: vehicle emissions represented by a hydrocarbon-like OA factor $(\mathrm{HOA} ; \mathrm{O} / \mathrm{C}=0.15 ; 17 \%$ of $\mathrm{OA}$ mass), food cooking activities represented by a cooking-influenced OA factor ( $\mathrm{COA} ; \mathrm{O} / \mathrm{C}=0.19 ; 22 \%$ of OA mass), and secondary organic aerosol (SOA) represented by a semi-volatile oxygenated OA factor (SV-OOA; O/C $=0.44 ; 27 \%$ of OA mass) and a low-volatility oxygenated OA factor (LV-OOA; $\mathrm{O} / \mathrm{C}=0.91 ; 34 \%$ of OA mass).
\end{abstract}

Our results indicate that air quality in SMA during KORUS-AQ was influenced strongly by secondary aerosol formation, with sulfate, nitrate, ammonium, SV-OOA, and LV-OOA together accounting for $76 \%$ of the $\mathrm{PM}_{1}$ mass. In particular, the formation of LV-OOA and sulfate was mainly promoted by elevated ozone concentrations and photochemical reactions during daytime, whereas SV-OOA and nitrate formation was contributed by both nocturnal processing of VOC and nitrogen oxides, respectively, and daytime photochemical reactions. In addition, lower nighttime temperature promoted gas-to-particle partitioning of semivolatile species and formation of SV-OOA and nitrate. During a period of 4 days (from 20 to 23 May ), LV-OOA increased dramatically and accounted for up to $41 \%$ of the $\mathrm{PM}_{1}$ mass. This intense LV-OOA formation event was associated with large enhancements of both anthropogenic and biogenic VOCs (e.g., isoprene and toluene), high concentration of $\mathrm{O}_{x}\left(=\mathrm{O}_{3}+\mathrm{NO}_{2}\right)$, strong solar radiation, and stagnant conditions, suggesting that it was mainly driven by local photochemical formation. We have also investigated the formation and evolution mechanisms of severe haze episodes. Unlike the winter haze events which were mainly caused by intense local emissions coupled with stagnant meteorological conditions, the spring haze events appeared to be influenced by both regional and local factors. For example, there were episodes of long-range transport of plumes followed by calm meteorology conditions, which promoted the formation and accumulation of 
local secondary species, leading to high concentrations of PM. Overall, our results indicate that PM pollutants in urban Korea originate from complex emission sources and atmospheric processes and that the concentrations and composition of PM are controlled by various factors, including meteorological conditions, local anthropogenic emissions, and upwind sources.

\section{Introduction}

Particulate matter (PM) in the atmosphere can reduce visibility, damage human health, and impact climate directly by absorbing and reflecting solar radiation and indirectly by modifying cloud formation and properties (IPCC, 2013; Pope III and Dockery, 2006; Pöschl, 2005). PM pollution in urban areas is commonly associated with elevated anthropogenic emissions, stagnant meteorological conditions, and regional transport of pollutants from upwind locations (Cao et al., 2012; Guo et al., 2014; Sun et al., 2014; Zheng et al., 2015; Molina, 2004; Young et al., 2015).

The Seoul Metropolitan Area (SMA) is one of the most populated and developed places in Korea and is ranked as the fourth largest metropolitan area in the world. SMA is experiencing persistent air quality problems despite continuous regulatory control efforts for many years. Aerosol concentration in this area often exceeds the $\mathrm{PM}_{2.5}$ annual standards set by the Ministry of Environment in Korea $\left(15 \mu \mathrm{g} \mathrm{m}^{-3}\right)$, as well as those by the United States Environmental Protection Agency (US EPA, $12 \mu \mathrm{g} \mathrm{m}^{-3}$ ) and the World Health Organization (WHO, $10 \mu \mathrm{g} \mathrm{m}^{-3}$ ).

SMA is the commercial, industrial, and residential center of South Korea, with a population of $\sim 24$ million and an area of $605.21 \mathrm{~km}^{2}$ (approximately $15 \mathrm{~km}$ in radius). Air quality in SMA is driven predominantly by local anthropogenic emissions but is also influenced by emissions from surrounding areas such as industrial emissions in the west of SMA and emissions from biogenic, agricultural and biomass burning sources in the east (Kim et al., 2010). Air quality in SMA can also be influenced by long-range transport of air pollutants. For example, due to its location in the central west of the Korean Peninsula facing the Yellow Sea in the west, air quality in SMA can be impacted heavily by continental outflows from the Asian continent (Kim et al., 2010). Furthermore, due to a confluence of a wide range of emissions, ranging from local to regional, marine to continental, and biogenic to anthropogenic, the interactions among these emissions are likely as important as the emissions themselves in determining the formation and evolution of particulate pollutants in SMA. Consequently, developing an effective mitigation strategy for air pollution in SMA remains a great challenge (Harrison and Yin, 2000).
In addition to various emission sources, previous studies have shown that the concentration and the composition of ambient aerosol in SMA are influenced by atmospheric processes and meteorological conditions as well (Heo et al., 2009; Kim et al., 2017). According to measurements by the Seoul Research Institute of Public Health and Environment, $\mathrm{PM}_{2.5}$ concentrations in SMA during the past 9 years were generally higher during winter (DJF; average $\pm 1 \sigma=30 \pm 16 \mu \mathrm{g} \mathrm{m}^{-3}$ ) and spring (MAM; $29 \pm 14 \mu \mathrm{g} \mathrm{m}^{-3}$ ) than in summer (JJA; $23 \pm 13 \mu \mathrm{g} \mathrm{m}^{-3}$ ) and fall (SON; $23 \pm 14 \mu \mathrm{g} \mathrm{m}^{-3}$ ). Previous studies have shown that elevated anthropogenic emissions (e.g., from heating) coupled with a lower planetary boundary layer (PBL) height and stagnant meteorological conditions are mainly responsible for poor air quality in Seoul during winter, although long-range transport of pollutants from upwind areas may have some influences as well (Kim et al., 2014, 2017). The severe air quality problem during spring in SMA is frequently driven by long-range transport of wind-blown dust (yellow dust) and smokes from fires from the west and northwest (Kim et al., 2010). In addition, compared to winter, photochemical formation of secondary aerosol is expected to be more intense due to increased solar radiation and higher temperature during spring and affects air quality in SMA more actively. However, so far there is little information available on the formation, properties and transport of atmospheric aerosol during spring in SMA, although a fundamental understanding of aerosol chemistry and dynamics is necessary for predicting how changes in atmospheric composition influence air quality in this region.

The Korea-US Air Quality Study (KORUS-AQ) is an international cooperative air quality field study that took place in Korea in spring 2016. This field study was aimed at integrating information from satellites, aircraft and ground measurements, and model simulations to better understand satellite performance and atmospheric composition and to improve model fidelity in simulating the current atmospheric state and possible future scenarios (KORUS-AQ mission whitepaper, 2015). One of the key scientific goals of KORUS-AQ is to determine the most important factors governing ozone photochemistry and aerosol evolution. Specifically, this study aims at addressing two questions for aerosol: (1) what portion of aerosol in SMA is comprised with secondary process and what are the major sources and factors to control its variation? (2) How important are local and regional influences on air quality in SMA?

As part of the KORUS-AQ, many aerosol, gas-phase, and meteorological measurements were made at several ground sites in SMA during spring. One of the sites was located on the Korea Institute of Science and Technology (KIST) campus, where a comprehensive, real-time dataset on sizeresolved chemical composition and number distribution of submicrometer particles $\left(\mathrm{PM}_{1}\right)$ was acquired - using an Aerodyne high-resolution time-of-flight aerosol mass spectrometer (HR-ToF-AMS) in parallel with a scanning mo- 


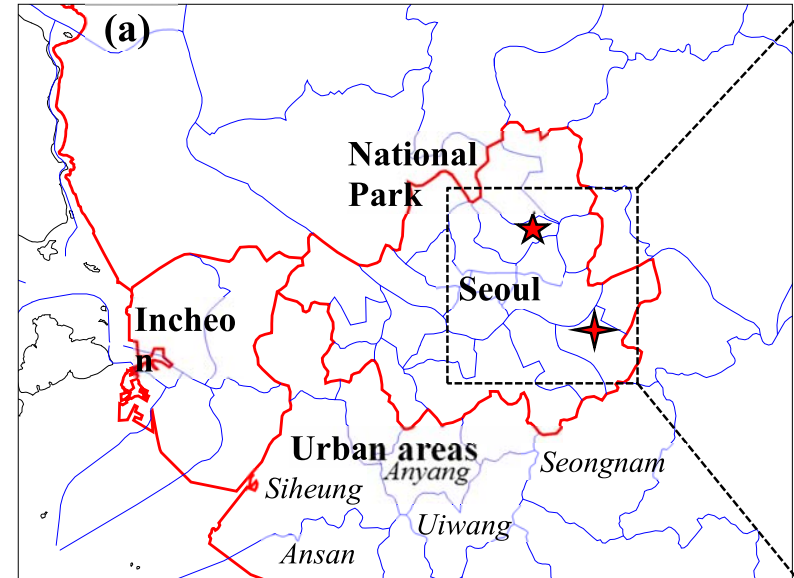

(c)

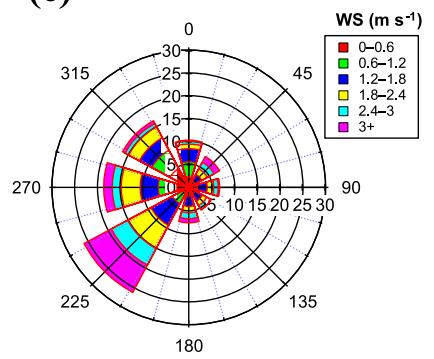

(d)



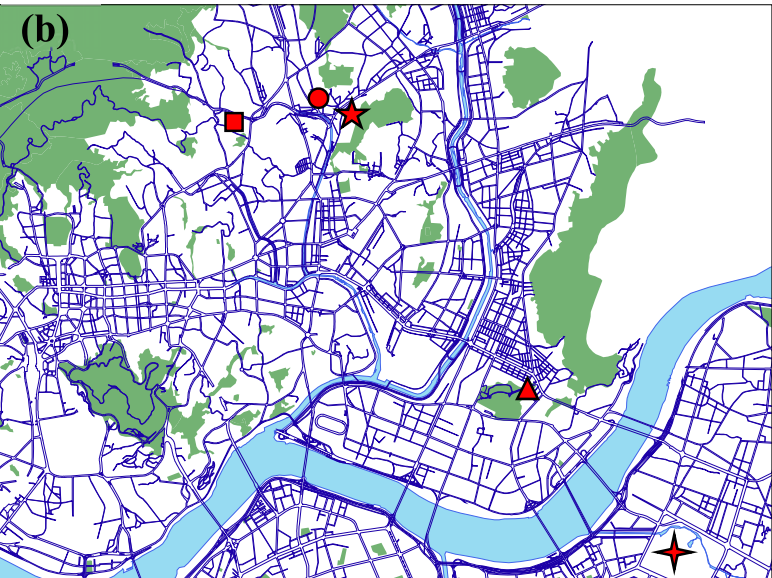

(e)

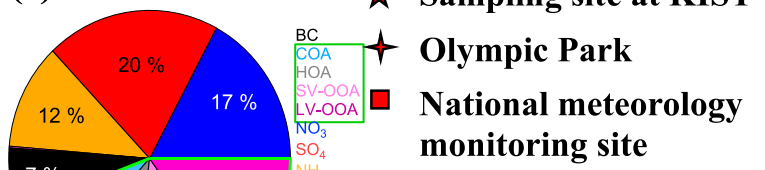

Sampling site at KIST monitoring site

O $\Delta$ National ambient monitoring site

Figure 1. (a) The map of SMA and surrounded by other nearby cities including Incheon where industrial facilities are located (west and south), agricultural and biogenic areas (east and south) and Bukhansan National Park (north); (b) the location of the sampling site in Seoul which is in the north-east of the city center and north of the Han River. Also shown is the other supersite located at Olympic Park. Blue lines shown in the figure indicate roadways; (c) wind rose plot for the entire study period; (d) bivariate polar plots of $\mathrm{PM}_{1}$ (non-refractory $\mathrm{PM}_{1}$ plus black carbon (BC)) concentrations (in $\mu \mathrm{g} \mathrm{m}^{-3}$ ); (e) average compositional pie chart of $\mathrm{PM}_{1}$ species and each of the OA factors over the whole campaign. The green outline indicates the fraction of total OA.

bility particle sizer (SMPS) for 2 months from 14 April to 15 June 2016. Here we report results from detailed analyses of this dataset. Specifically, in addition to the high-resolution mass spectra (HRMS) and elemental ratios determined by the HR-ToF-AMS, distinct organic aerosol (OA) factors were derived by analyzing HRMS to gain insights into the sources and atmospheric processing of OA. Our goals are to reach a detailed understanding of the chemical properties of aerosol particles in SMA and to elucidate the emission sources and formation and transformation processes that drive their temporal and diurnal variations over this region during spring. Given that SMA is located in a region impacted by both local emissions from anthropogenic and biogenic activities and long-range transported emissions from upwind sources, complex pollutant interactions tend to occur on fast timescales. An in-depth understanding of these processes will be useful for developing parameterization for future satellite retrievals, specifically for geostationary (GEO) satellites, which offer higher time and spatial resolution information compared to low Earth orbit (LEO), including detailed daily variation patterns of atmospheric pollutants.
Here, we report (1) the mass concentrations, size distributions, chemical composition, and temporal and diurnal variations of $\mathrm{PM}_{1}$ species; (2) the characteristics and dynamic variations of $\mathrm{OA}$ sources and processes using positive matrix factorization (PMF); (3) discussions on the intensive formation of secondary species; and (4) a case study of a haze event.

\section{Experimental methods}

\subsection{Sampling site description}

The KORUS-AQ field campaign took place in SMA from 14 April to 15 June 2016. A map of the SMA with the location of the ground-based sites is given in Fig. 1a. Measurements reported in this paper were performed on the fifth floor of a building on the campus of KIST $\left(37.60^{\circ} \mathrm{N}, 127.05^{\circ} \mathrm{E}\right.$, $60 \mathrm{~m}$ a.s.1.) at $\sim 7 \mathrm{~km}$ to the northwest of Olympic Park, which is the main supersite of KORUS-AQ. Detailed descriptions of the KIST site can be found in Kim et al. (2017). Briefly, KIST is located $\sim 400 \mathrm{~m}$ from a busy highway and is 
surrounded by a residential area and a commercial area; thus, the air quality at this site tends to be influenced by abundant anthropogenic and primary sources. During spring, KIST, and SMA in general, are influenced by highly consistent winds from the west and southwest (Fig. 1c, d), where a number of cities and large-scale industrial facilities are located (Fig. 1a) and are significant sources of $\mathrm{NO}_{x}$ and $\mathrm{SO}_{x}(\mathrm{Kim}$ et al., 2017). However, sometimes, the dominant wind blew from the north and east, where emissions from agricultural and biogenic sources are generally more intense (Fig. S1 in the Supplement). In this paper, pollutants from inside and outside of the SMA are treated as "local"- and "regional"scale pollutants, respectively. Air pollution episodes associated with transport from outside of Korea are considered "long-range transport".

\subsection{Measurements}

At the KIST site $\left(37.60^{\circ} \mathrm{N}, 127.05^{\circ} \mathrm{E}\right), \mathrm{NR}^{\mathrm{PM}} \mathrm{M}_{1}$ components including sulfate, nitrate, ammonium, chloride, and organics as well as their size distributions were measured by an Aerodyne HR-ToF-AMS (DeCarlo et al., 2006) at a time resolution of $3 \mathrm{~min}$. In parallel, black carbon (BC) concentration was measured every minute with a multi-angle absorption photometer (MAAP; Thermo Fisher Scientific, Waltham, MA, USA). Both instruments sampled downstream of a $\mathrm{PM}_{2.5}$ cyclone (URG Corp.; Chapel Hill, NC, USA) and Nafion dryer (Perma Pure LLC, USA). The number size distributions of aerosol particles with mobility diameters between 20 and $1000 \mathrm{~nm}$ were measured by a scanning mobility particle sizer (SMPS 3080; TSI Inc., St Paul, MN, USA). The concentrations of trace gases (e.g., $\mathrm{CO}, \mathrm{O}_{3}, \mathrm{NO}_{2}$ and $\left.\mathrm{SO}_{2}\right)$ were acquired at the Gireum site $\left(37.61^{\circ} \mathrm{N}, 127.03^{\circ} \mathrm{E}\right)$ operated by the Seoul Research Institute of Public Health and Environment. Meteorological measurement data such as ambient temperature, relative humidity $(\mathrm{RH})$, wind speed and wind direction were obtained from the nearby Jungreung site $\left(37.61^{\circ} \mathrm{N}, 127.00^{\circ} \mathrm{E}\right)$ maintained by the Korea meteorological administration. VOC data were obtained from the Gwangjin supersite $\left(37.55^{\circ} \mathrm{N}, 127.09^{\circ} \mathrm{E}\right)$ maintained by the Seoul Research Institute of Public Health and Environment. The data reported in this paper are in local time, which is Korea Standard Time (KST) and is $9 \mathrm{~h}$ earlier than Universal Coordinated Time (UTC).

In this study, the HR-ToF-AMS was operated in the standard configuration and obtained mass spectra (MS) and particle time-of-flight (PToF) data. Furthermore, the HR-ToFAMS was operated under the "V" and " $W$ " modes, where high sensitivity but low mass resolution was achieved in "V" mode, and low sensitivity but high mass resolution was achieved in "W" mode. Ionization efficiency (IE) and particle sizing calibrations were performed following standard protocols (Canagaratna et al., 2007) immediately before, during, and at the end of the measurement period.

\subsection{AMS data analysis}

\subsubsection{Basic HR-ToF-AMS data analysis}

HR-ToF-AMS data were processed and analyzed using the standard toolkit (SeQUential Igor data RetRiEval (SQUIRREL; ver. 1.57I), and PIKA (ver. 1.16I)) (ToF-AMS software downloads, 2017); within Igor Pro (Wavemetrics, Lake Oswego, OR, USA). Details on the data processing procedures are described in previous papers (e.g., Aiken et al., 2008; Allan et al., 2004; Jimenez et al., 2003; Setyan et al., 2012). Briefly, the standard fragmentation table described by Allan et al. (2004) was used, with some modifications, to process the raw MS. The modifications were based on data from six measurements of filtered ambient air to properly remove the background contributions from gas-phase signals to particle measurements. Specifically, adjustments were made to the measured $\mathrm{CO}_{2}^{+}(\mathrm{m} / \mathrm{z}=44)$ signal to remove the contributions from gas phase $\mathrm{CO}_{2}$ as well as the ${ }^{16} \mathrm{O}^{+}$to ${ }^{14} \mathrm{~N}^{+}$ ratio for air signals at $m / z=29$ based on measurements of particle-free ambient air. Relative ionization efficiencies (RIE) of 1.1, 1.07, and 3.938 were used for nitrate, sulfate, and ammonium, respectively, based on values determined from calibrations using pure $\mathrm{NH}_{4} \mathrm{NO}_{3}$ and $\left(\mathrm{NH}_{4}\right)_{2} \mathrm{SO}_{4}$ particles. A composition-dependent collection efficiency (CDCE) was applied to the data based on an algorithm by Middlebrook et al. (2012). The campaign average $( \pm 1 \sigma)$ CDCE was $0.5 \pm 0.01$ (Fig. S2).

The quantification of NR-PM $\mathrm{PM}_{1}$ species was validated through comparisons between the total $\mathrm{PM}_{1}$ mass $\left(\mathrm{PM}_{1}=\mathrm{NR}-\mathrm{PM}_{1}+\mathrm{BC}\right)$ and the apparent particle volume measured by the SMPS (Fig. S3). As shown in Fig. S3c, the SMPS-measured particle volume correlated strongly with the AMS measured total mass $\left(R^{2}=0.88\right)$. The slope from the linear fit of $\mathrm{PM}_{1}$ mass against SMPS volume is $1.24 \mathrm{~g} \mathrm{~cm}^{-3}$, which was lower than the average $( \pm 1 \sigma)$ particle density of $1.50( \pm 0.08) \mathrm{g} \mathrm{cm}^{-3}$ estimated using the measured chemical composition in this study (Zhang et al., 2005a) (Fig. S3d). Note that the average $( \pm 1 \sigma)$ organic aerosol density was estimated to be $1.21( \pm 0.07) \mathrm{g} \mathrm{cm}^{-3}$ based on the approach reported in Kuwata et al. (2012) using the average elemental ratios of bulk OA determined using the Aiken ambient method (Aiken et al., 2008) (Table S3, Fig. S5). The diurnal pattern of the AMS total mass-based size distribution also compared well with the volume-based size distribution from SMPS measurements throughout the day (Fig. 5a and b). In addition, total $\mathrm{PM}_{1}$ mass (=NR-PM measured by AMS $+\mathrm{BC}$ ) correlates well with $\mathrm{PM}_{2.5}$ mass measured using a beta attenuation mass monitor (Thermo, FH62C14) at the Gireum site ( $\sim 5 \mathrm{~km}$ to the west of the KIST site), showing the $67 \%$ of $\mathrm{PM}_{2.5}$ (Fig. S4). The detection limits of the main chemical components by the HR-ToF-AMS are listed in Table S1, and are generally far lower than the observed concentrations. All the reported 
mass concentrations in this study are based on ambient conditions.

The elemental ratios between oxygen, carbon, hydrogen, nitrogen and sulfur as well as the organic mass to carbon ratio $(\mathrm{OM} / \mathrm{OC})$ of $\mathrm{OA}$ were determined by analyzing the $\mathrm{W}$ mode high-resolution mass spectra (HRMS) data using both the Aiken ambient method (Aiken et al., 2008) and the updated method recently reported by Canagaratna et al. (2015). The ratios reported by the two methods correlate very well and the Canagaratna method reports higher values by factors of 1.28, 1.02 and 1.28 for O / C, H / C and OM / OC, respectively (Table S3 and Fig. S5). Unless otherwise indicated, the $\mathrm{O} / \mathrm{C}, \mathrm{H} / \mathrm{C}$, and $\mathrm{OM} / \mathrm{OC}$ ratios reported in this paper are all from the Canagaratna et al. (2015) method.

\subsubsection{Positive matrix factorization (PMF) of the HR-ToF-AMS mass spectra}

The HRMS acquired during this study were analyzed using PMF. The analysis was performed using the PMF2 algorithm in robust mode (Paatero and Tapper, 1994), with the PMF Evaluation Toolkit (PET ver 2.05) (PMF_Evaluation_Tool_Software, 2017; Ulbrich et al., 2009). The data and error matrices were prepared according to the protocol described by Ulbrich et al. (2009) and outlined in Table 1 of Zhang et al. (2011).

The PMF analysis was performed on the combined matrices of organic and inorganic ions using the method reported in Sun et al. (2012) since including the inorganic signals allows better separation and evaluation of physically meaningful organic aerosol factors. For example, the solutions of the combined matrix provide information on the distributions of inorganic signals among different sources and the association between inorganic and organic aerosol components in individual factors. This information is helpful for interpreting the sources, chemical characteristics, and evolution processes of different types of OA (Sun et al., 2012; Zhou et al., 2017).

The combined matrix includes organic ions in the range of $\mathrm{m} / \mathrm{z}=12$ to $120 \mathrm{amu}$ and the major ions of inorganic species, i.e., $\mathrm{SO}^{+}, \mathrm{SO}_{2}^{+}, \mathrm{HSO}_{2}^{+}, \mathrm{SO}_{3}^{+}, \mathrm{HSO}_{3}^{+}$, and $\mathrm{H}_{2} \mathrm{SO}_{4}^{+}$for sulfate; $\mathrm{NO}^{+}$and $\mathrm{NO}_{2}^{+}$for nitrate; and $\mathrm{NH}^{+}, \mathrm{NH}_{2}^{+}$, and $\mathrm{NH}_{3}^{+}$ for ammonium. Chloride-related ions were not included because of their low signal-to-noise ratios during this study. The ion signals in the HRMS and error matrices analyzed with PMF were expressed in nitrate-equivalent concentrations. The number of factors $(p)$ in the solution was explored from one up to nine with varying rotational parameters $(-1 \leq$ FPEAK $\leq 1$, in increments of 0.1$)$. After a detailed evaluation of the key diagnostics, i.e., mass spectral signatures, diurnal profiles, and correlations with external tracers, as outlined in Zhang et al. (2011), the six-factor solution (four organic factors and two inorganic factors) with fPeak $=0$ was selected for further analyses. A summary of the key diagnostics is presented in Fig. S6 in the Supple- ment. The six-factor solution was found to be very stable as the mass distributions of the factors remained relatively constant between fPeaks -0.7 and +0.7 (Fig. S6c). Figure S7 shows the mass spectra and the time series of the five- and seven-factor solutions. The five-factor solution was unable to deconvolve a meaningful COA factor, whereas the temporal variations of the organic factors from the seven-factor solution showed indications of factor splitting and mixing of inorganics. For example, two separate nitrate and sulfate factors (factors 1 and 2) as well as one mixed factor of nitrate and sulfate (factor 3) were identified. Given the fact that having only two inorganic factors (i.e., the six-factor solution set) did not influence the separation of the other organic factors, it was not necessary to go for a higher number of factors. Consequently, the six-factor solution, which resolved HOA, COA, two types of OOA and two inorganics, was chosen as it appears to best represent OA sources and processes in the SMA during KORUS-AQ.

In this study, we also performed regular PMF analysis on the OA matrix only (Ulbrich et al., 2009), but the analysis was unsuccessful at retrieving meaningful factors (Fig. S8). A minimum of four factors was needed to adequately account for the observed variance, but the solution showed indications of mixing factors without being able to resolve a meaningful HOA factor. One the other hand, the five-factor solution, although it was able to resolve two POA factors representing $\mathrm{COA}$ and $\mathrm{HOA}$, respectively, showed indications of splitting and mixing of OOA factors (Fig. S8).

\subsubsection{Back-trajectory and bivariate conditional probability function analyses}

In this study, $96 \mathrm{~h}$ back-trajectories were calculated every hour using version 4.9 of the Hybrid Single-Particle Lagrangian Integrated Trajectory (HYSPLIT) model (Draxler, 1997, 2012) for the sampling periods from 14 April to 15 June 2016. Every trajectory was released at half of the mixing height at the KIST (latitude: $37.60^{\circ} \mathrm{N}$; longitude: $127.05^{\circ} \mathrm{E}$ ) and the average starting height for the backtrajectories for the entire period of this study was approximately $190 \mathrm{~m}$ (Fig. S9). Note that half of the mixing height was automatically calculated by the HYSPLIT model. To identify pollutant characteristics in different predominant transport patterns, cluster analysis was performed on the trajectories using HYSPLIT4, and five clusters were identified according to their similarity in spatial distribution. In addition, back-trajectories were calculated separately for episode periods, i.e., an organic-dominant period (from 20 to 23 May) and a haze period (from 26 to 31 May) to identify the directions and characteristics of significantly influenced plumes during those periods.

In addition, a conditional probability function (CPF) (Kim et al., 2003) was performed to estimate the local sources and their impacts on $\mathrm{PM}_{1}$ composition and individual organic aerosol sources from PMF analysis, using wind directions 


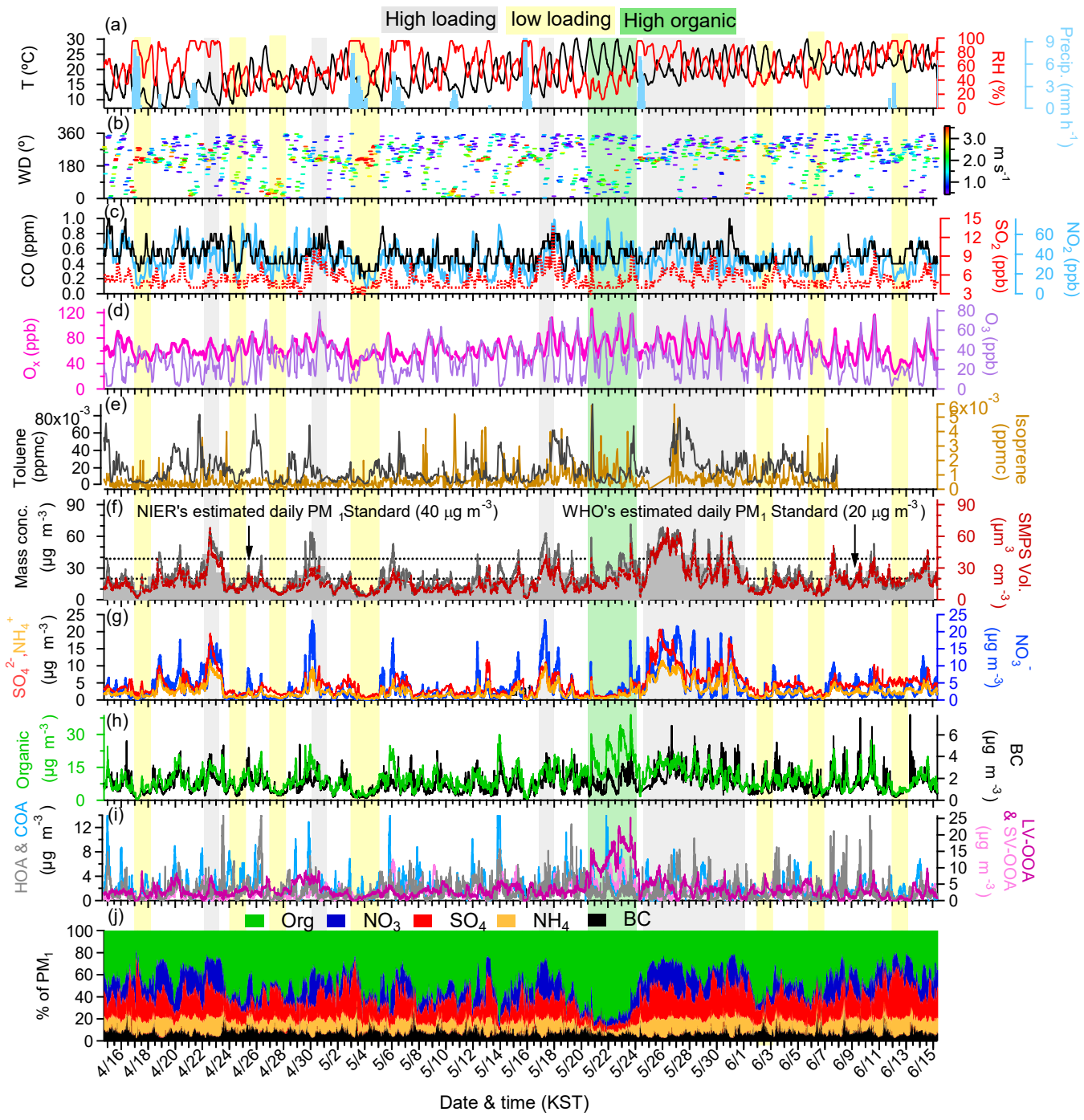

Figure 2. Overview of the temporal variations of submicron aerosols at the Korea Institute of Science and Technology (KIST) in SMA from 14 April to 15 June 2016: (a) time series of ambient air temperature ( $T$ ), relative humidity (RH), and precipitation (Precip.); (b) time series of wind direction (WD; $0^{\circ}$ indicates north, $90^{\circ}$ indicates east), with colors showing different wind speeds (WS); (c) time series of $\mathrm{CO}_{2} \mathrm{SO}_{2}$, and $\mathrm{NO}_{2} ;(\mathbf{d})$ time series of $\mathrm{O}_{x}\left(\mathrm{NO}_{2}+\mathrm{O}_{3}\right)$ and $\mathrm{O}_{3} ;$ (e) time series of toluene and isoprene; (f) time series of total particulate matter (PM $)$ and scanning mobility particle sizer (SMPS) volume concentrations; also shown are the $24 \mathrm{~h}$ averaged $\mathrm{PM}_{1}+\mathrm{BC}$ with bars. Estimated NIER and WHO daily $\mathrm{PM}_{1}$ standards (40 and $20 \mu \mathrm{g} \mathrm{m}^{-3}$, respectively) are also shown with dashed lines for the comparisons; (g) time series of the nitrate $\left(\mathrm{NO}_{3}^{-}\right)$, sulfate $\left(\mathrm{SO}_{4}^{2-}\right)$ and ammonium $\left(\mathrm{NH}_{4}^{+}\right)$aerosols; (h) time series of the organic (Org.) and $\mathrm{BC}$ aerosols; (i) time series of each factor derived from the positive matrix factorization (PMF) analysis; (j) time series of the mass fractional contribution of organic aerosols (Org.), nitrate $\left(\mathrm{NO}_{3}^{-}\right)$, sulfate $\left(\mathrm{SO}_{4}^{2-}\right)$, ammonium $\left(\mathrm{NH}_{4}^{+}\right)$, and $\mathrm{BC}$ to total $\mathrm{PM}_{1}$.

coupled with the time series of concentration of each species. The CPF plots represent the probability that a specific compound or source is located in a certain wind direction, assisting in finding local point sources.

\section{Results and discussions}

\subsection{Overview of submicron aerosol characteristics}

\subsubsection{Temporal variations of $\mathrm{PM}_{1}$ composition and chemical properties}

The overall characteristics and temporal variations of $\mathrm{PM}_{1}$ at KIST during KORUS-AQ are shown in Fig. 2, along with the time series of gaseous pollutants, e.g., $\mathrm{CO}, \mathrm{SO}_{2}, \mathrm{O}_{3}$, and 
$\mathrm{O}_{x}\left(\mathrm{O}_{x}=\mathrm{O}_{3}+\mathrm{NO}_{2}\right.$; Herndon, 2008), and meteorological conditions (RH, temperature, wind direction, wind speed). From 14 April to 15 June 2016, the average concentration of $\mathrm{PM}_{1}$ (=NR-PM $+\mathrm{BC}$ ) was $22.1 \mu \mathrm{g} \mathrm{m}^{-3}$, ranging from 0.76 to $71 \mu \mathrm{g} \mathrm{m}^{-3}$. In addition to a severe haze episode with daily $\mathrm{PM}_{1}$ concentration above $30 \mu \mathrm{g} \mathrm{m}^{-3}$ that continued for 6 days during 26-31 May, shorter haze episodes (daily $\mathrm{PM}_{1}$ $>30 \mu \mathrm{g} \mathrm{m}^{-3}$ ) occurred several times as well (Fig. 2). In between high loading periods, aerosol concentration was relatively low, with daily $\mathrm{PM}_{1}$ concentration typically lower than $14 \mu \mathrm{g} \mathrm{m}^{-3}$. The dramatic variations in $\mathrm{PM}_{1}$ mass concentrations (0.76 to $71 \mu \mathrm{g} \mathrm{m}^{-3}$ for $2.5 \mathrm{~min}$ average; Fig. 2f) and other pollutants (Fig. 2c, d), such as $\mathrm{CO}(0.2$ to $1 \mathrm{ppm}$ for $1 \mathrm{~min}$ average), $\mathrm{O}_{3}$ ( 3 to $82 \mathrm{ppb}$ for a $1 \mathrm{~min}$ average), and $\mathrm{NO}_{2}$ (6 to $76 \mathrm{ppb}$ for a $1 \mathrm{~min}$ average) reflect the impacts of dynamic changes in emission sources, atmospheric processes, and meteorological conditions on air quality in SMA during spring.

The variations of individual $\mathrm{PM}_{1}$ components were substantial as well (Fig. 2g, h). For instance, the mass concentration of organics ranged from 0.39 to $39 \mu \mathrm{g} \mathrm{m}^{-3}$ during this study, and on 20 May, it rapidly increased from 7.6 to $24 \mu \mathrm{g} \mathrm{m}^{-3}$ over a period of $\sim 25 \mathrm{~min}$ and reached as high as $39 \mu \mathrm{g} \mathrm{m}^{-3}$ on 23 May (Fig. 2h). The accumulation of OA during this episode appeared to be related to a large enhancement of VOCs (e.g., isoprene, toluene) (Fig. 2e) coupled with a high concentration of $\mathrm{O}_{x}\left(\mathrm{O}_{3}+\mathrm{NO}_{2}\right)$, strong solar radiation and stagnant conditions, which together promoted intensive formation of secondary organic aerosol (SOA). The mass concentration of sulfate also varied widely from 0.19 to $21 \mu \mathrm{g} \mathrm{m}^{-3}$ during the entire period and increased from 1.2 to $20 \mu \mathrm{g} \mathrm{m}^{-3}$ from 24 to 26 May, likely due to favorable meteorological conditions for sulfate formation and influences from the regional and/or long-range transport. The variation of nitrate concentration was substantial too, from 0.05 to $23.4 \mu \mathrm{g} \mathrm{m}^{-3}$, with low concentrations generally occurring during daytime due to high temperature and low humidity. Investigation of these different events (e.g., haze periods, high organic) can provide insights into how different sources and atmospheric processes influence air quality in this region. Detailed discussions on the processes that led to high aerosol pollution events are presented in Sect. 3.3 and 3.4 .

Since the molar equivalent ratios of total inorganic anions to cations for $\mathrm{NR}^{-\mathrm{PM}_{1}}$ $\left(=\left(\mathrm{SO}_{4}^{2-} / 48+\mathrm{NO}_{3}^{-} / 62+\mathrm{Cl}^{-} / 35.5\right) /\left(\mathrm{NH}_{4}^{+} / 18\right)\right)$

were close to 1 (Fig. S10), submicron aerosols appeared to be bulk balanced in observed cations and anions and the ionic species were mainly present in the forms of $\mathrm{NH}_{4} \mathrm{NO}_{3}$, $\left(\mathrm{NH}_{4}\right)_{2} \mathrm{SO}_{4}$, and $\mathrm{NH}_{4} \mathrm{Cl}$. Possible sources of ammonia/ammonium in the SMA include on-road vehicle emissions, neutralizer usage in industry, and agricultural emissions at the outskirts of SMA.

Overall, organics were an important aerosol component, on average accounting for $44 \%$ of $\mathrm{PM}_{1}$ mass.
$\mathrm{POA} \quad(=\mathrm{HOA}+\mathrm{COA})$ and $\mathrm{SOA} \quad(=\mathrm{SV}-\mathrm{OOA}+\mathrm{LV}-$ OOA) accounted for 59 and $41 \%$, respectively, of the OA mass (detailed discussions on OA sources are provided in Sect. 3.3). Secondary inorganic aerosol $($ SIA $=$ sulfate + nitrate + ammonium $)$ on average accounted for $37 \%$ of the total $\mathrm{PM}_{1}$ mass, with sulfate contributing the most (20\%) (Fig. 1e). The non-refractory chloride concentrations measured by the HR-ToF-AMS were mostly below the detection limit during the present study. On average, $\sim 24 \%$ of $\mathrm{PM}_{1}$ was composed of primary materials $(\mathrm{POA}+\mathrm{BC})$, with the remainder $(76 \%)$ being secondary species $\left(\mathrm{NO}_{3}^{-}+\mathrm{SO}_{4}^{2-}+\mathrm{NH}_{4}^{+}+\mathrm{SOA}\right.$ ) (Fig. 1e), indicating that the aerosol pollution problem in SMA during spring is mainly caused by secondary aerosol formation.

The average concentration and composition of $\mathrm{PM}_{1}$ measured in SMA during this study were significantly different from those measured during wintertime. For instance, compared to winter, the average $\mathrm{PM}_{1}$ concentration was lower during spring ( $22 \mathrm{vs.} 27 \mathrm{\mu g} \mathrm{m}^{-3}$ ), the mass fraction of sulfate was higher ( 20 vs. $10 \%$ ) but that of nitrate was lower (17 vs. $24 \%$ ), and the total contribution of secondary species was higher (76 vs. $64 \%$ ) (Kim et al., 2017). As discussed in the following sections, these differences reflect the differences between the two seasons in meteorological conditions and emissions and formation processes of air pollutants.

\subsubsection{Diurnal patterns of $\mathbf{P M}_{1}$ composition and formation processes}

As shown in Fig. 3, the diurnal cycles were vastly different among different aerosol species. The daily variation of the average concentration of sulfate was relatively flat and its mass-based size distribution shows a persistent accumulation mode that peaks at $650 \mathrm{~nm}\left(D_{\mathrm{va}}\right)$ (Fig. S11). These observations together with a dispersed feature of the sulfate bivariate polar plot (Fig. S13) indicate that particulate sulfate over SMA is mainly associated with regional sources, such as the industrial facilities located in the west and southwest of SMA (Fig. 1) (Kim et al., 2017). Indeed, the polar plot of $\mathrm{SO}_{2}$ shows a strong association of high $\mathrm{SO}_{2}$ concentrations with westerly and southwesterly winds (Fig. S13). Figure 4c shows the diurnal patterns of springtime sulfate, $\mathrm{SO}_{2}$, and the molar ratio of sulfate $\left(\mathrm{SO}_{4}^{2-}\right)$ to $\mathrm{SO}_{x}\left(=\mathrm{SO}_{4}^{2-}+\mathrm{SO}_{2}\right)$, i.e., $f_{\mathrm{SO}_{4}}$, which is an indicator of the extent of $\mathrm{SO}_{2}$ oxidation (Kaneyasu et al., 1995). $f_{\mathrm{SO}_{4}}$ decreased from 0.24 to 0.21 between 06:00 and 10:00, during which $\mathrm{SO}_{2}$ increased by $\sim 1 \mathrm{ppb}$ (Fig. 4a). This change was likely due to the breaking of the boundary layer which mixed down air masses more enriched in $\mathrm{SO}_{2}$ from aloft. Also, $f_{\mathrm{SO}_{4}}$ increased gradually from 11:00 till 06:00 of the next day. For the daytime increase from 11:00 to 18:00, the lifetime of $\mathrm{SO}_{2}$ was calculated to be $\sim 11$ days, using the temperaturedependent daytime reaction rate constant, $k$ (8.75$9.24 \times 10^{-13} \mathrm{~cm}^{3} \mathrm{~s}^{-1}$ ), for $\mathrm{SO}_{2}+\mathrm{OH}+M \rightarrow \mathrm{H}_{2} \mathrm{SO}_{4}$ (Burkholder et al., 2015) and the corresponding $\mathrm{OH}$ con- 

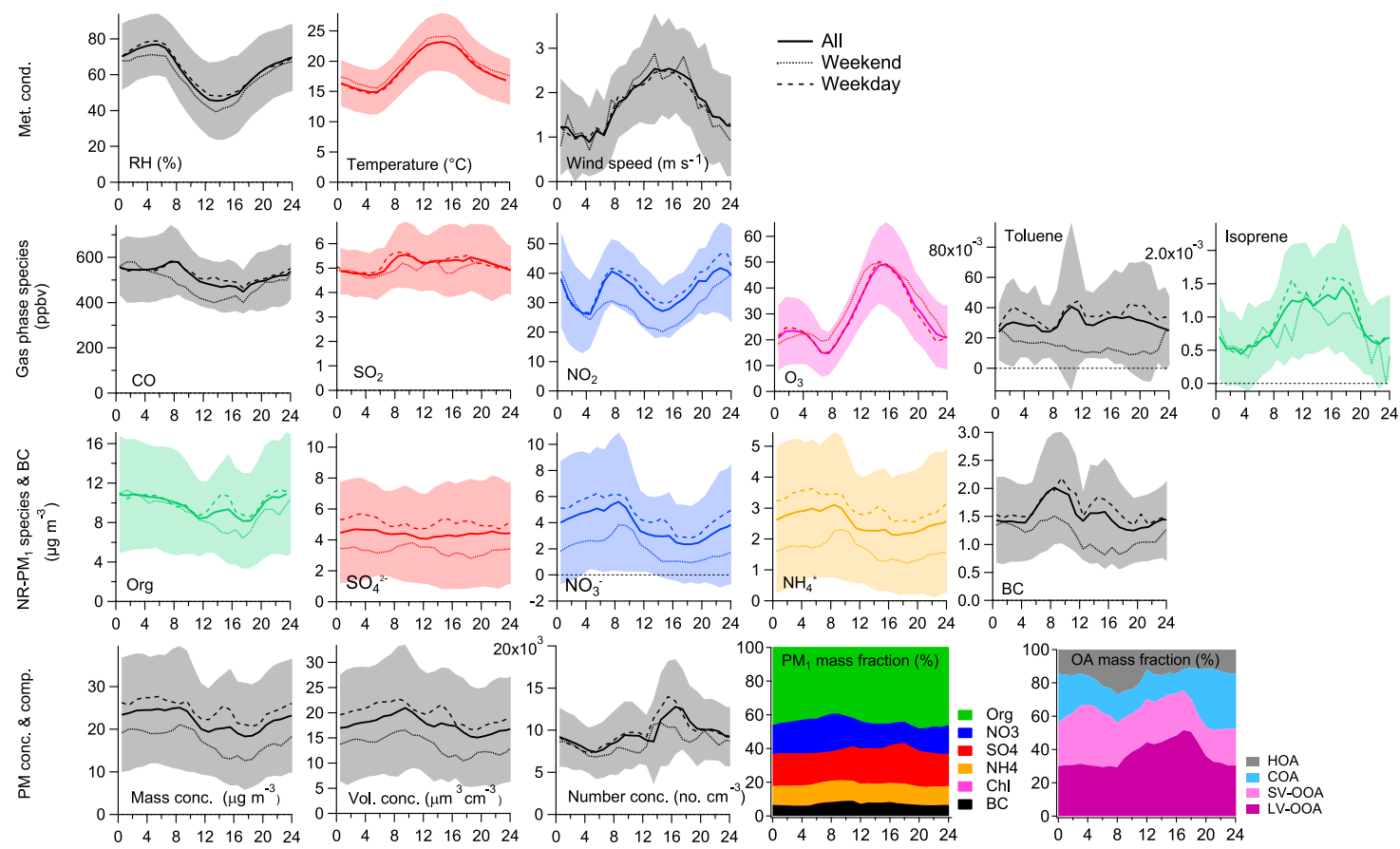

Hour of day (KST)

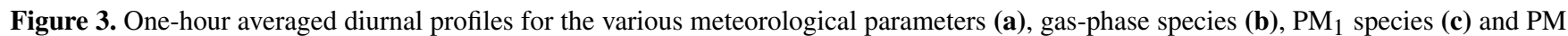

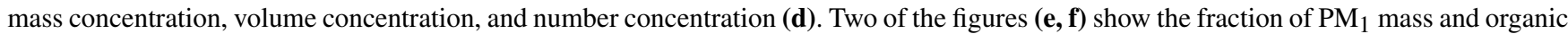
mass, respectively.
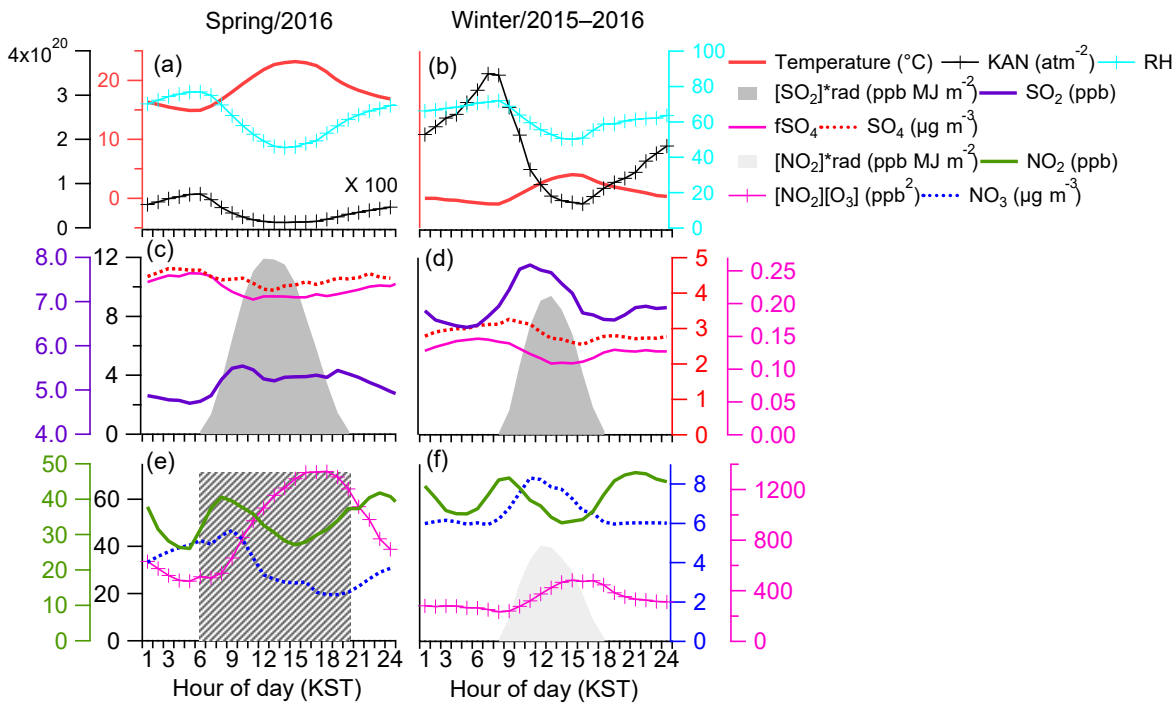

Figure 4. One-hour averaged diurnal profiles for sulfate, nitrate and various parameters and proxies for formation pathways in winter (5 December 2015-21 January 2016) and spring (14 April-15 June 2016); temperature, relative humidity and $K_{\mathrm{AN}}$ as the equilibrium constant for gas-to-particle partitioning for ammonium nitrate in (a) 2016 and (b) 2015. The $1 \mathrm{~h}$ averaged diurnal $\mathrm{profiles}$ of $\mathrm{SO}_{2}, \mathrm{SO}_{4}^{2-}$, $f \mathrm{SO}_{4}$ and $\left[\mathrm{SO}_{2}\right]$ times solar radiation as a proxy for daytime $\mathrm{H}_{2} \mathrm{SO}_{4}$ formation in (c) spring 2016 and (d) winter 2015; the $1 \mathrm{~h}$ averaged diurnal profiles of $\mathrm{NO}_{2}, \mathrm{NO}_{3}$, and $\left[\mathrm{NO}_{2}\right]\left[\mathrm{O}_{3}\right]$ as a proxy for nighttime formation of $\mathrm{HNO}_{3}$ and subsequently particulate nitrate, and $\left[\mathrm{NO}_{2}\right]$ times solar radiation as a proxy for daytime $\mathrm{HNO}_{3}$ formation in (e) spring 2016 and (f) winter 2015. 
centration $\left(1.2 \times 10^{6}\right.$ molecules $\left.\mathrm{cm}^{-3}\right)$ which is in the range of other cities such as Tokyo (Miyazaki et al., 2006) and Beijing (Rao et al., 2016). This suggests that the localized photochemical reaction of $\mathrm{SO}_{2}+\mathrm{OH}$ is not the major process for controlling $\mathrm{SO}_{4}^{2-}$ concentrations during this period. Nighttime increase in $f_{\mathrm{SO}_{4}}$ can be explained by the aqueous-phase oxidation of $\mathrm{SO}_{2}$ facilitated by the high $\mathrm{RH}$ condition. Indeed, $\mathrm{SO}_{2}$ began to decrease at $\sim 19: 00$, when RH increased and T decreased (Fig. 4a). Possible oxidants during night are $\mathrm{NO}_{2}$ and $\mathrm{O}_{3}$, although $\mathrm{SO}_{2}$ oxidation by $\mathrm{O}_{3}$ and $\mathrm{NO}_{2}$ are both $\mathrm{pH}$-dependent and the reaction rates increase with $\mathrm{pH}$ (Seinfeld and Pandis, 2006). $\mathrm{NH}_{3}$ concentration in SMA is likely high since aerosol particles in this region are bulk balanced in observed cations and anions (Fig. S10), suggesting that oxidation by both $\mathrm{O}_{3}$ and $\mathrm{NO}_{2}$ could occur actively. Furthermore, $\mathrm{NO}_{2}$ has been investigated as an important oxidant in aerosol water under hazy conditions (Cheng et al., 2016). However, it is still open to other possible oxidation pathways since any formation of $\mathrm{H}_{2} \mathrm{SO}_{4}$ will immediately suppress the $\mathrm{pH}$, although particles may begin as neutral. Thus the $\mathrm{NO}_{2}$ and $\mathrm{O}_{3}$ pathways may potentially become self-limiting in particles unless there is an abundance of gas-phase $\mathrm{NH}_{3}$ to compensate. Similar trends were observed during winter as well, although higher $\mathrm{SO}_{2}$ and lower $\mathrm{SO}_{4}^{2-}$ and $f_{\mathrm{SO}_{4}}$ were observed (Fig. 4d). Lower $\mathrm{SO}_{2}$ concentration during spring was likely due to less coal combustion for heating and the higher $\mathrm{SO}_{4}^{2-}$ and $f_{\mathrm{SO}_{4}}$ were due to more efficient conversion of $\mathrm{SO}_{2}$ to $\mathrm{SO}_{4}^{2-}$ during spring under stronger solar radiation or more regional transport of $\mathrm{SO}_{4}^{2-}$. Previous study indicates that nighttime aqueous-phase processing was an important driver for sulfate formation during winter in SMA (Kim et al., 2017). However, gas-phase photochemical oxidation of $\mathrm{SO}_{2}$ and regional transport appear to be more important contributors to $\mathrm{SO}_{4}^{2-}$ during spring. Indeed, $f_{\mathrm{SO}_{4}}$ correlated less well with $\mathrm{RH}$ during spring than during winter $\left(R^{2}=0.27\right.$ vs. 0.59) (Fig. S14).

Unlike sulfate, nitrate shows more dynamic diurnal cycles during both spring and winter. Overall, nitrate concentration was lower in spring than in winter despite faster photochemical production. This is due to higher temperature (Fig. 4a, b), which drives the evaporation of ammonium nitrate, particularly during spring daytime. Indeed, a depression of nitrate concentration occurred during the daytime of spring, whereas a midday peak (between 09:00 and 15:00) due to photochemical formation of nitrate was observed during winter. The overnight increase in nitrate during springtime was likely driven by enhanced gas-to-particle partitioning of ammonium nitrate associated with lower temperature as well as nighttime formation of nitrate (e.g., through $\mathrm{N}_{2} \mathrm{O}_{5}$ hydrolysis), which is consistent with the high concentrations of $\mathrm{O}_{3}$ $(\sim 20 \mathrm{ppb})$ and $\mathrm{NO}_{2}(\sim 42 \mathrm{ppb})$ throughout the night $(18: 00$ 06:00). However, the peak nitrate concentration (at $\sim 09: 00$ ) occurred $3 \mathrm{~h}$ later than the peaking of the ammonium nitrate

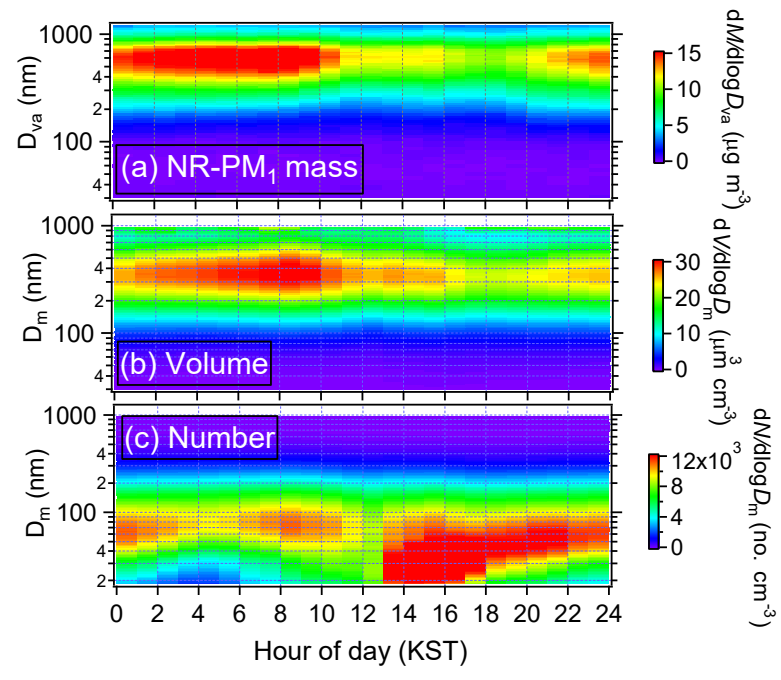

Figure 5. (a) Diurnal variations of the size distribution of NR$\mathrm{PM}_{1}$ mass from the AMS (in vacuum aerodynamic diameter, $D_{\mathrm{va}}$ ); (b) volume from the SMPS (in mobility diameter, $D_{\mathrm{m}}$ ) and (c) number concentrations from the SMPS.

equilibrium constant $\left(K_{\mathrm{AN}}\right)(\sim 06: 00)$, which might be due to the mixing down of a nocturnal residual layer (Prabhakar et al., 2017). The equilibrium constant $k_{\mathrm{AN}}$ can be calculated as

$k_{\mathrm{AN}}=k(298) \exp \left\{a\left(\frac{298}{T}-1\right)+b\left[1+\ln \left(\frac{298}{T}\right)-\frac{298}{T}\right]\right\}$

where $T$ is the ambient temperature in Kelvin, $k(298)=3.36 \times 10^{16}\left(\mathrm{~atm}^{-2}\right), a=75.11$, and $b=-13.5$ (Seinfeld and Pandis, 2006). Significant nitrate formation through nighttime chemistry occurred during winter as well, due to lower temperature and relatively high nighttime concentrations of $\mathrm{NO}_{2}$ and $\mathrm{O}_{3}$. However, compared to springtime, the product of $\mathrm{NO}_{2}$ and $\mathrm{O}_{3}\left(\left[\mathrm{NO}_{2}\right]\left[\mathrm{O}_{3}\right]\right)$ during winter was $\sim$ a factor of 2 lower during night (Fig. 4a, b), indicating that nighttime nitrate formation is more significant in spring. $\left[\mathrm{NO}_{2}\right]\left[\mathrm{O}_{3}\right]$ is a proxy for nighttime formation rate of particulate nitrate, since the reaction between $\mathrm{NO}_{2}$ and $\mathrm{O}_{3}$ produces $\mathrm{N}_{2} \mathrm{O}_{5}$ and nitrate radical $\left({ }^{\circ} \mathrm{NO}_{3}\right)$, which can react heterogeneously to form $\mathrm{HNO}_{3}$ and subsequently particulate nitrate (Young et al., 2016).

Organics dominated $\mathrm{PM}_{1}$ composition throughout the day, with $1 \mathrm{~h}$ average mass fractions varying from 40 to $48 \%$ (Fig. 3). The average diurnal profile of organics showed elevated concentration overnight and a clear daytime peak from 13:00 to 18:00. The nighttime enhancement was consistent with the accumulation of primary emissions from traffic and cooking due to low boundary layer height and stagnant air conditions, whereas the daytime enhancement was likely the outcome of photochemical formation of SOA. Detailed discussions are given in Sect. 3.2. 


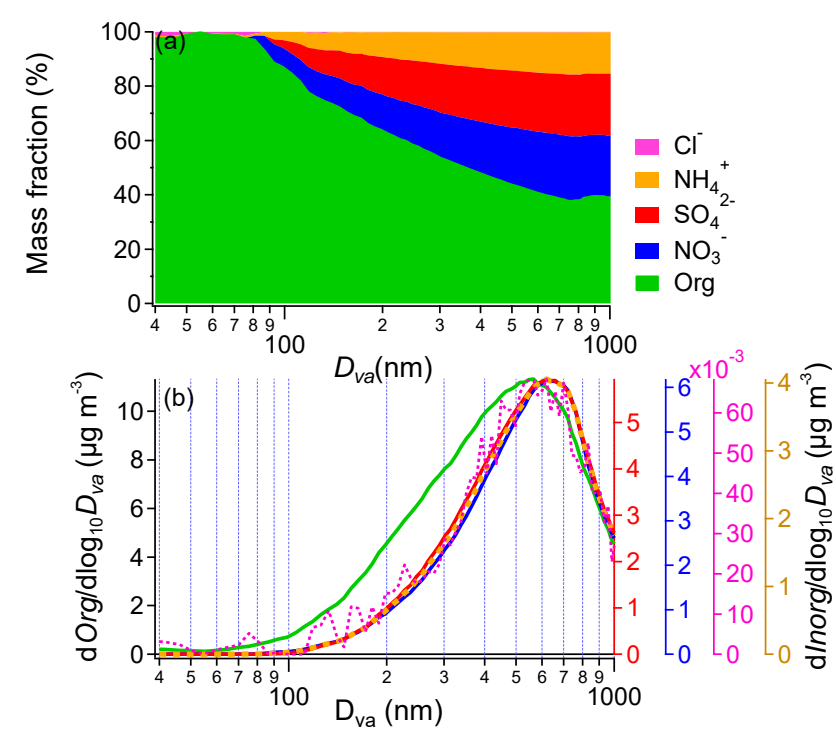

Figure 6. (a) Averaged mass fractional contributions of each NR$\mathrm{PM}_{1}$ species to the total NR-PM 1 mass as a function of size; (b) campaign-averaged size distributions for individual NR-PM 1 species.

BC presented two peaks, one occurring during morning rush hour (07:00-10:00) and the other in the afternoon between 14:00 and 15:00 (Fig. 3). Similar trends were observed with HOA (Sect. 3.3) and particle number concentration (Fig. 3), indicating that both peaks of BC were contributed by vehicle emissions. The morning rush hour peak of primary air pollutants is commonly observed in many other studies as well as during winter at the same site (Kim et al., 2017); however, the enhancement of these species in the afternoon, when elevated mixed layer height tends to dilute primary pollutants, is unique. In addition, the afternoon increase in $\mathrm{BC}, \mathrm{HOA}$, and particle number concentration began at $\sim 12: 00$ and reached a maximum around 16:00 (Figs. 3 and 8). This time period corresponded to the effective transport of air masses from urban and industrial areas located in the south and southwest of the KIST site (Fig. 1a) by a predominant southwesterly flow during 11:00-17:00 (Fig. S1). With an average wind speed of $\sim 2 \mathrm{~m} \mathrm{~s}^{-1}$, the southwesterly wind would take $\sim 1-5 \mathrm{~h}$ to bring plumes from upwind urban sites that are $\sim 7.2 \mathrm{~km}$ (e.g., Anyang) to $36 \mathrm{~km}$ (e.g., Incheon, Siheung and Ansan) away from the KIST site (Fig. 1). Furthermore, the large increase in particle number concentration (Fig. 3) and the apparent growth of ultrafine particles (Fig. 5c) between $\sim 12: 00$ and 16:00 suggest that new particle events might have happened in association with transport of plumes from the southwest.

\subsubsection{Size distributions of the main components of $\mathrm{PM}_{1}$}

Figure 5 shows the average mass-based size distributions of NR-PM 1 species over the entire KORUS-AQ campaign and their daily evolution behaviors. Sulfate, nitrate and ammonium in spring all show very similar size distribution profiles, with a mode peaking at around $650 \mathrm{~nm}$ in vacuum aerodynamic diameter ( $D_{\mathrm{va}}$; DeCarlo et al., 2004), suggesting that SIA were internally mixed. The springtime size distribution profiles of SIA at KIST are somewhat different than those observed during winter, which peaked around 400-500 nm (Kim et al., 2017). The finding of bigger particle sizes during spring than in winter could be due to faster particle growth rates caused by higher photochemical activity during spring. Similarly, a recent study in Beijing reported that the peak size of SIA during summer $\left(600 \mathrm{~nm}\right.$ in $\left.D_{\mathrm{va}}\right)$ was bigger than during winter (350 $\mathrm{nm}$ ) (Hu et al., 2016).

The average mass-based size distribution of organics was in general wider than those of inorganic species, with a peak at $\sim 550 \mathrm{~nm}$ and a shoulder peaking at $\sim 300 \mathrm{~nm}$ and extending down to $\sim 60 \mathrm{~nm}$ (Fig. 6b). Similar observations were made in the winter at SMA and a number of urban areas in China and North America (e.g., Kim et al., 2017, and references therein). The wider size distribution of organics reflected the contributions made by both primary and secondary aerosols, i.e., the ultrafine mode dominated by primary aerosols and the accumulation mode comprised mainly of secondary aerosols. The mode of the organics in spring $(500-600 \mathrm{~nm})$ was bigger than in winter $(400 \mathrm{~nm})$, likely for the same reason that the size mode of SIA was bigger during spring - enhanced photochemical activity for secondary aerosol formation in spring than in winter as well as fewer contributions of primary particles to fine-mode particles from vehicular, cooking, and biomass burning sources.

The organic fraction was above $50 \%$ across the whole size range and almost $100 \%$ in ultrafine-mode particles (especially in $D_{\mathrm{va}}<100 \mathrm{~nm}$ ), whereas SIA dominated $\left(>60 \%\right.$ of $\left.\mathrm{NR}-\mathrm{PM}_{1}\right)$ in accumulation-mode particles, with $D_{\text {va }}>500 \mathrm{~nm}$ in spring (Fig. 6).

\subsection{Characteristics and source apportionment of organic aerosol}

Overall, on a mass basis, OA from SMA during spring was composed of approximately $66 \%$ carbon, $24 \%$ oxygen, $8 \%$ hydrogen, and $2 \%$ nitrogen (Fig. 7). The average carbon-normalized molecular formula of $\mathrm{OA}$ was $\mathrm{C}_{1} \mathrm{H}_{1.67} \mathrm{O}_{0.49} \mathrm{~N}_{0.02} \mathrm{~S}_{0.002}$, yielding an average organic massto-carbon ratio (OM/OC) of 1.82. The average elemental ratios, which were calculated using the updated elemental analysis method (Canagaratna et al., 2015), are within the range of the revised values observed at other urban locations (Canagaratna et al., 2015; Young et al., 2016, and references therein). Upon examining the diurnal patterns of the atomic ratios among elements in $\mathrm{OA}$, we found that $\mathrm{O} / \mathrm{C}$ and $\mathrm{OM} / \mathrm{OC}$ ratios had similar patterns but that the pattern of $\mathrm{H} / \mathrm{C}$ was different, due to variations in the relative contributions of POA and SOA. Also, nitrogen-to-carbon (N/C) ratios showed a distinct diurnal profile with a bimodal fea- 

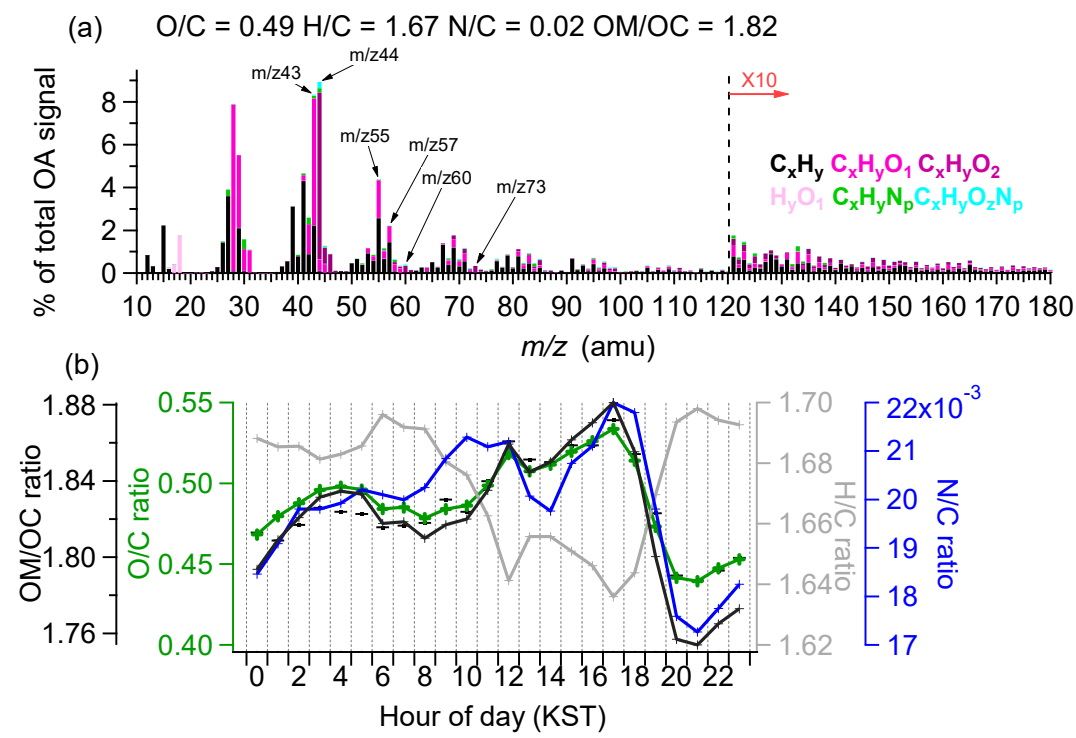

\begin{tabular}{|c|c|c|c|c|c|}
\hline \multicolumn{2}{|c|}{$\begin{array}{l}\text { Average } \mathbf{P M}_{1} \\
\text { composition } \\
\left(22.1 \mu \mathrm{g} \mathrm{m}^{-3}\right)\end{array}$} & \multicolumn{2}{|c|}{ Average OA ratios } & \multicolumn{2}{|c|}{$\begin{array}{l}\text { Average OA spectral } \\
\text { composition }\end{array}$} \\
\hline Org & $9.76 \mu \mathrm{g} \mathrm{m}^{-3}$ & $\mathrm{O} / \mathrm{C}$ & 0.49 & $\mathrm{C}_{\mathrm{x}} \mathrm{H}_{\mathrm{y}}^{+}$ & $47 \%$ \\
\hline $\mathrm{C}$ & $66 \%$ & $\mathrm{H} / \mathrm{C}$ & 1.67 & $\mathrm{H}_{\mathrm{y}} \mathrm{O}_{1}^{+}$ & $2.4 \%$ \\
\hline $\mathrm{O}$ & $24 \%$ & $\mathrm{~N} / \mathrm{C}$ & 0.02 & $\mathrm{C}_{\mathrm{x}} \mathrm{H}_{\mathrm{y}} \mathrm{O}_{1}^{+}$ & $31 \%$ \\
\hline $\mathrm{H}$ & $8 \%$ & $\mathrm{~S} / \mathrm{C}$ & 0.002 & $\mathrm{C}_{\mathrm{x}} \mathrm{H}_{\mathrm{y}} \mathrm{O}_{2}^{+}$ & $14 \%$ \\
\hline $\mathrm{N}$ & $2 \%$ & $\mathrm{OM} / \mathrm{OC}$ & 1.82 & $\mathrm{C}_{\mathrm{x}} \mathrm{H}_{\mathrm{y}} \mathrm{N}_{\mathrm{p}}^{+}$ & $3.3 \%$ \\
\hline & & & & $\mathrm{C}_{\mathrm{x}} \mathrm{H}_{\mathrm{y}} \mathrm{N}_{\mathrm{p}} \mathrm{O}_{\mathrm{z}}^{+}$ & $2.3 \%$ \\
\hline
\end{tabular}

Figure 7. (a) Average high-resolution mass spectrum of OA colored by the different ion families. The average elemental ratios for the OA fraction are described; (b) average diurnal profiles of the organic matter to organic carbon (OM / OC), oxygen to carbon (O / C), hydrogen to carbon $(\mathrm{H} / \mathrm{C})$, and nitrogen to carbon $(\mathrm{N} / \mathrm{C})$, where the $\mathrm{O} / \mathrm{C}, \mathrm{H} / \mathrm{C}$ and $\mathrm{OM} / \mathrm{OC}$ elemental ratios were determined using the updated method (Canagaratna et al., 2015). The table shown is the overview of the OA compositions in SMA during KORUS-AQ.

ture peaking at 10:00 and 16:00, similar to the $\mathrm{O} / \mathrm{C}$ diurnal profile.

In this study, four distinct $\mathrm{OA}$ factors were determined, including two types of POA (HOA and COA) and two types of OOA (LV-OOA and SV-OOA). The O / C ratios for LVOOA, SV-OOA, COA, and HOA were 0.91, 0.44, 0.19, and 0.15 , respectively. An overview of the chemical composition and temporal and diurnal variations of the four OA factors are shown in Figs. 2i and 8. LV-OOA (34\%) represents the largest fraction of the OA mass, followed by SV-OOA $(27 \%)$, COA (22\%) and HOA (17\%) (Fig. S17).

Briefly, HOA showed the typical picket fence fragmentation pattern as commonly seen in freshly emitted vehicle POA, with major peaks at $m / z$ 's $41,43,55$, and 57 , which are mostly composed of $\mathrm{C}_{3} \mathrm{H}_{5}^{+}, \mathrm{C}_{3} \mathrm{H}_{7}^{+}, \mathrm{C}_{4} \mathrm{H}_{7}^{+}$, and $\mathrm{C}_{4} \mathrm{H}_{9}^{+}$ions, respectively (Fig. 8a). HOA also showed strong correlations with tracer ions, $\mathrm{C}_{3} \mathrm{H}_{7}^{+}(r=0.87), \mathrm{C}_{4} \mathrm{H}_{7}^{+}(r=0.81), \mathrm{C}_{4} \mathrm{H}_{9}^{+}$ $(r=0.95)$, and $\mathrm{C}_{5} \mathrm{H}_{11}^{+}(r=0.96)$ (Fig. S18 and Table S3). The average ratio of $\mathrm{HOA} / \mathrm{BC}$ was 1.03 , which is lower than the ratio for light-duty vehicles (1.4) and higher than that for diesel trucks (0.5) (Ban-Weiss et al., 2008), reflecting the fact that SMA traffic comprises both gasoline and diesel vehicles. Similar HOA/BC values were observed in other large urban areas, such as Pittsburgh (1.41 \pm 0.22 ; Zhang et al., 2005b), New York City (1.29) (Sun et al., 2011), Mexico City (1.25) (Aiken et al., 2009), and Xianghe, China (0.91) (Sun et al., 2016). A lower HOA/BC ratio was observed in winter in Korea (0.58), probably due to the impacts of biomass burning (Kim et al., 2017).

As widely reported in highly populated cities, a COA factor was resolved in SMA as well. The COA showed good correlations in time series with the key tracer ions commonly used to justify the presence of aerosols from cooking-related activities (He et al., 2004; Adhikary et al., 2010; Mohr et al., 2009, 2012; Zhao et al., 2007; Ge et al., 2012; Sun et al., 2011, 2013; Young et al., 2016; Allan et al., 2010; Huang et al., 2010; Hayes et al., 2013; Dall'Osto et al., 2013), such as $\mathrm{C}_{3} \mathrm{H}_{3} \mathrm{O}^{+}(m / z, 55 ; r=0.75), \mathrm{C}_{3} \mathrm{H}_{5} \mathrm{O}^{+}(m / z 57 ; r=0.61)$, $\mathrm{C}_{5} \mathrm{H}_{8} \mathrm{O}^{+}(m / z, 84 ; r=0.89), \mathrm{C}_{6} \mathrm{H}_{10} \mathrm{O}^{+}(m / z 98 ; r=0.99)$ and $\mathrm{C}_{7} \mathrm{H}_{12} \mathrm{O}^{+}(m / z$ 112; $r=0.70)$ (Fig. S18 and Table S2). 

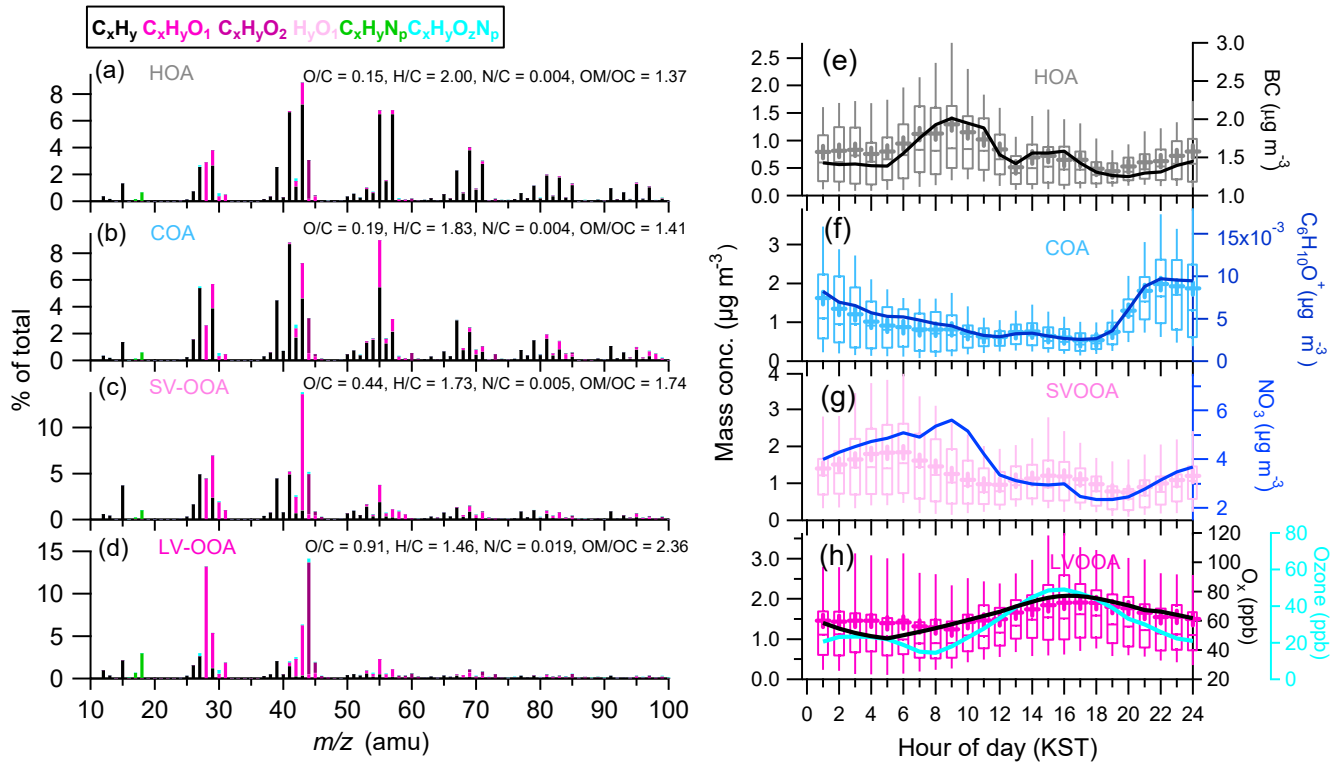

Figure 8. Overview of the results from PMF analysis including high-resolution mass spectra of the (a) hydrocarbon-like organic aerosol (HOA), (b) cooking OA (COA), (c) semi-volatile oxygenated OA (SV-OOA), and (d) low-volatility oxygenated OA (LV-OOA) colored by different ion families; (e-h) average diurnal profiles of each of the OA factors (the 90th and 10th percentiles are denoted by the whiskers above and below the boxes, the 75th and 25 th percentiles are denoted by the top and bottom of the boxes, the median values are denoted by the horizontal line within the box, and the mean values are denoted by the colored markers) with various tracer species.
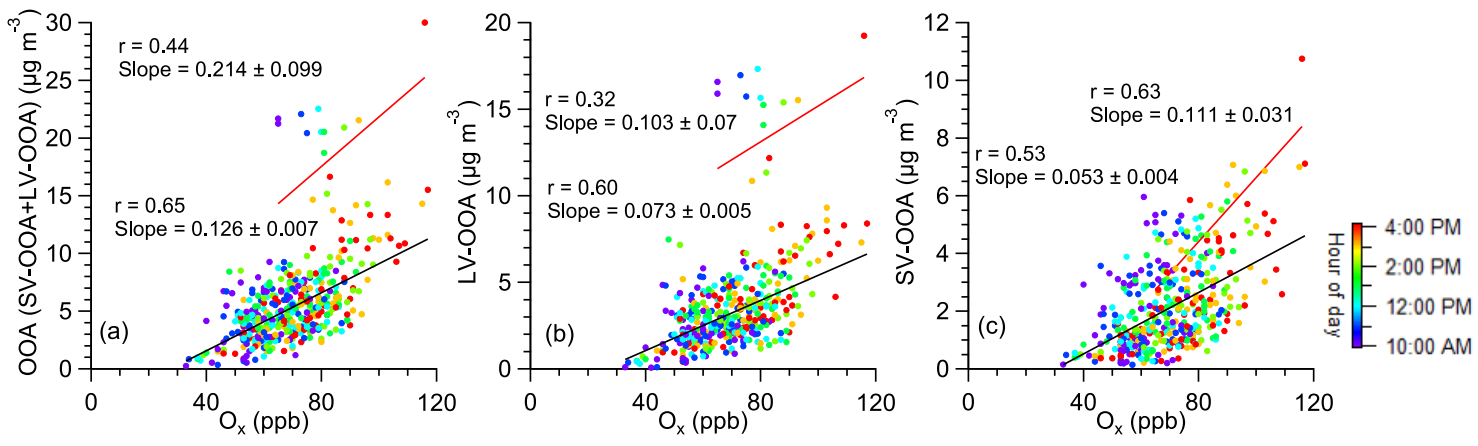

Figure 9. Scatter plots of (a) OOA; (b) LV-OOA; and (c) SV-OOA vs. $\mathrm{O}_{x}$ during daytime (10:00-16:00) in spring 2015. Note that the fittings for the organic dominant period (20 May, 17:00-24 May, 00:00) are colored in red, and for the rest of the periods they are colored in black.

It was also a major contributor to the signals of $\mathrm{C}_{5} \mathrm{H}_{8} \mathrm{O}^{+}$, $\mathrm{C}_{6} \mathrm{H}_{10} \mathrm{O}^{+}$, and $\mathrm{C}_{7} \mathrm{H}_{12} \mathrm{O}^{+}$, accounting for 62,94 , and $67 \%$, respectively (Fig. S16). The mass spectrum of the COA determined in this study was almost identical to the COA spectrum determined in winter 2015-2016 at the same site (Figs. 8b and S15) (Kim et al., 2017). In addition, as shown in Fig. S19b, the ratios between $f 55$ and $f 57$ for OA in Seoul increased proportionally as the fractional contribution of COA to total OA increased, forming a "V" shape with two edges defined by the COA and the HOA factors from several urban AMS datasets (Mohr et al., 2012). Furthermore, the diurnal profile of the COA displayed a large enhancement at evening starting between $\sim 18: 00$ and 19:00, corresponding to dinner time, and a small noon-time peak at $\sim 12: 00$, corresponding to lunch time, although the features do not reflect fully the expected cooking activities. Nevertheless, these observations generally corroborate the association of the COA factor with cooking activities. The relatively weak noon-time enhancement of the COA was probably due to strong dilution of primary emissions caused by convection and elevated boundary layer height. It is also possibly related to Korean cooking habits. Previous AMS studies reported COA factors with less pronounced patterns at noon or evening as well (Hayes et al., 2013). In addition, the COA of this study on average accounted for $\sim 18 \%$ of the total OA mass during lunch time and $\sim 37 \%$ during dinner time, which are within 
the values observed for COA in Beijing (Sun et al., 2016, and references therein). Nevertheless, it is important to caution that the noon-time and nighttime peaks could be influenced by photochemical formation of SOA and evening POA emissions coupled with reduced boundary layer height, respectively. In addition, while the COA tracer ions mentioned above tend to represent fatty acids which are usually a significant component of cooking aerosols (He et al., 2004; Mohr et al., 2009; To et al., 2000; Zheng et al., 1997), they can also be contributed by other sources such as plant wax, fossil fuel, soil particles, and SOA (Wang et al., 2006; Zhao et al., 2014). For these reasons, it is possible that the COA factor identified in this study might contain significant contributions from sources other than cooking activities, similar to situations reported in several other studies (Dall'Osto et al., 2013; Mohr et al., 2009, 2012; Hayes et al., 2013). Furthermore, a recent study reported that the relative ionization efficiency (RIE) of cooking OA tends to be higher than the typical RIE of 1.4 used for organic aerosol quantification (Reyes-Villegas et al., 2018), suggesting that cooking aerosol concentrations were likely overestimated in this study.

Besides the two POA factors, two OOA factors were identified, and both showed major ion fragments representative of oxidized organics, e.g., $\mathrm{CO}_{2}^{+}(m / z 44)$ and $\mathrm{C}_{2} \mathrm{H}_{3} \mathrm{O}^{+}(\mathrm{m} / z$ 43). SV-OOA $(\mathrm{O} / \mathrm{C}=0.56 ; \mathrm{H} / \mathrm{C}=1.90) \mathrm{re}-$ sides within the region representing fresher $\mathrm{SOA}$ in the triangle plots in Fig. S19, whereas the LV-OOA factor is characterized by a high $\mathrm{O} / \mathrm{C}$ ratio $(=0.91)$, indicating aged and highly oxidized OA, respectively. It was found to account for an average of $61 \%$ of the OA mass (Fig. S17a), with LVOOA and SV-OOA being 34 and $27 \%$, respectively. Both SV-OOA and LV-OOA correlated positively with $\mathrm{O}_{x}$ during the afternoon ( $r=0.53,0.6$, respectively), and the correlation between total SOA $(=\mathrm{LV}-\mathrm{OOA}+\mathrm{SV}-\mathrm{OOA})$ and $\mathrm{O}_{x}$ was even higher $(r=0.65$; Fig. 9a), indicating that afternoon SOA formation was strongly impacted by photochemistry. This observation is consistent with Herndon et al. (2008), who observed a strong correlation between OOA and $\mathrm{O}_{x}$ in photochemically processed urban plumes from Mexico City. The average OOA $/ \mathrm{O}_{x}$ ratio observed in the present study $\left(0.13 \mu \mathrm{g} \mathrm{m}^{-3} \mathrm{ppbv}^{-1}\right)$ is within the range of values from Mexico City and other megacities, including Tokyo, Los Angeles and Paris (0.13-0.18) (Zhang et al., 2015).

\subsection{Impacts of intense SOA formation on haze}

$\mathrm{PM}_{1}$ concentration jumped from 11 to $55 \mu \mathrm{g} \mathrm{m}^{-3}$ between 17:00 and 17:45 on 20 May, during which concentrations of all $\mathrm{PM}_{1}$ species (except for $\mathrm{COA}$ ), $\mathrm{SO}_{2}, \mathrm{NO}_{2}$, and biogenic and anthropogenic VOCs (e.g., isoprene and toluene) increased sharply (Fig. 2h). As shown in Fig. S20, the onset of this pollution episode was associated with a change in wind direction from southeast to northwest, indicating that it was mainly caused by transport of polluted air masses. Wind speed was low and wind direction alternated between north and east during the next 3 days, and the concentrations of most air pollutants rose and fell in correlation with the wind shifts. However, LV-OOA remained elevated after the initial sharp rise from 5.6 to $16 \mu \mathrm{g} \mathrm{m}^{-3}$ and increased to a maximum concentration of $\sim 25 \mu \mathrm{g} \mathrm{m}^{-3}$ on 23 May. SOA (= SV-OOA + LV-OOA) was a dominant aerosol component throughout the entire episode (20 May 17:00 to 24 May 0:00) and on average accounted for $\sim 60 \%$ of the $\mathrm{PM}_{1}$ mass (Fig. 10a). Since this episode was characterized by high daytime $\mathrm{O}_{3}$ concentration, air temperature, and solar radiation and elevated VOC concentrations (Fig. 2), SOA production was likely fast. In addition, the meteorological conditions were generally stagnant (e.g., slow wind speed and low mixing height) during this period (Rapid Science Synthesis Report, 2017), facilitating the accumulation of pollutants. Overall, intense photochemical reactions, high concentrations of gaseous precursors, and stagnant atmospheric conditions were likely responsible for the intense formation and accumulation of SOA during this episode. For example, as shown in Fig. 9, the correlation between SV-OOA and $\mathrm{O}_{x}$ during this period was tight and showed a slope (i.e., SV-OOA $/ \mathrm{O}_{x}$ ratio) twice as high as the rest of the study $\left(0.11 \mu \mathrm{g} \mathrm{m}^{-3} \mathrm{ppb}^{-1}\right.$ vs. $\left.0.053 \mu \mathrm{g} \mathrm{m}^{-3} \mathrm{ppb}^{-1}\right)$. This is an indication that SOA was formed more efficiently during this high SOA episode. However, the correlations of LV-OOA and total OOA $=(\mathrm{LV}-\mathrm{OOA}+\mathrm{SV}-\mathrm{OOA})$ vs. $\mathrm{O}_{x}$ were both poor during this high $\mathrm{OA}$ episode, suggesting that in addition to photochemical reactions, other factors such as aging processes which occurred under the stagnant air flow condition likely contributed to the high concentration of SOA as well.

On the other hand, formation of secondary inorganic aerosol species was limited during this event. One of the reasons was that air masses that arrived at the KIST site during this period (20 May, 17:00-24 May, 00:00) mainly originated from the east (Fig. 9c), where $\mathrm{SO}_{2}$ emission sources are sparse, thus containing low sulfate concentrations. Another reason was that temperature was high $\left(24 \pm 3^{\circ} \mathrm{C}\right)$ and RH was low ( $36 \pm 11 \%)$ during this period, unfavorable for particulate nitrate formation. These results indicate that SOA formation could be a leading cause of haze episodes in SMA during springtime.

\subsection{Regional and local influences on haze events}

Haze episodes occur often in East Asia, including Seoul, Korea (e.g., Kim et al., 2017, and references therein). Many investigations were conducted in China and suggest that the formation of severe haze pollution is a combined result of stagnant meteorological conditions associated with intense secondary aerosol formation, regional transport and primary emissions (Huang et al., 2014; Sun et al., 2010, 2014; Herndon et al., 2008; Wang et al., 2016a, b; Zheng et al., 2015). Our investigation of the occurrence of haze episodes in Seoul during winter 2015-2016 suggested that accumulation of primary pollutants and enhanced formation of secondary pollu- 

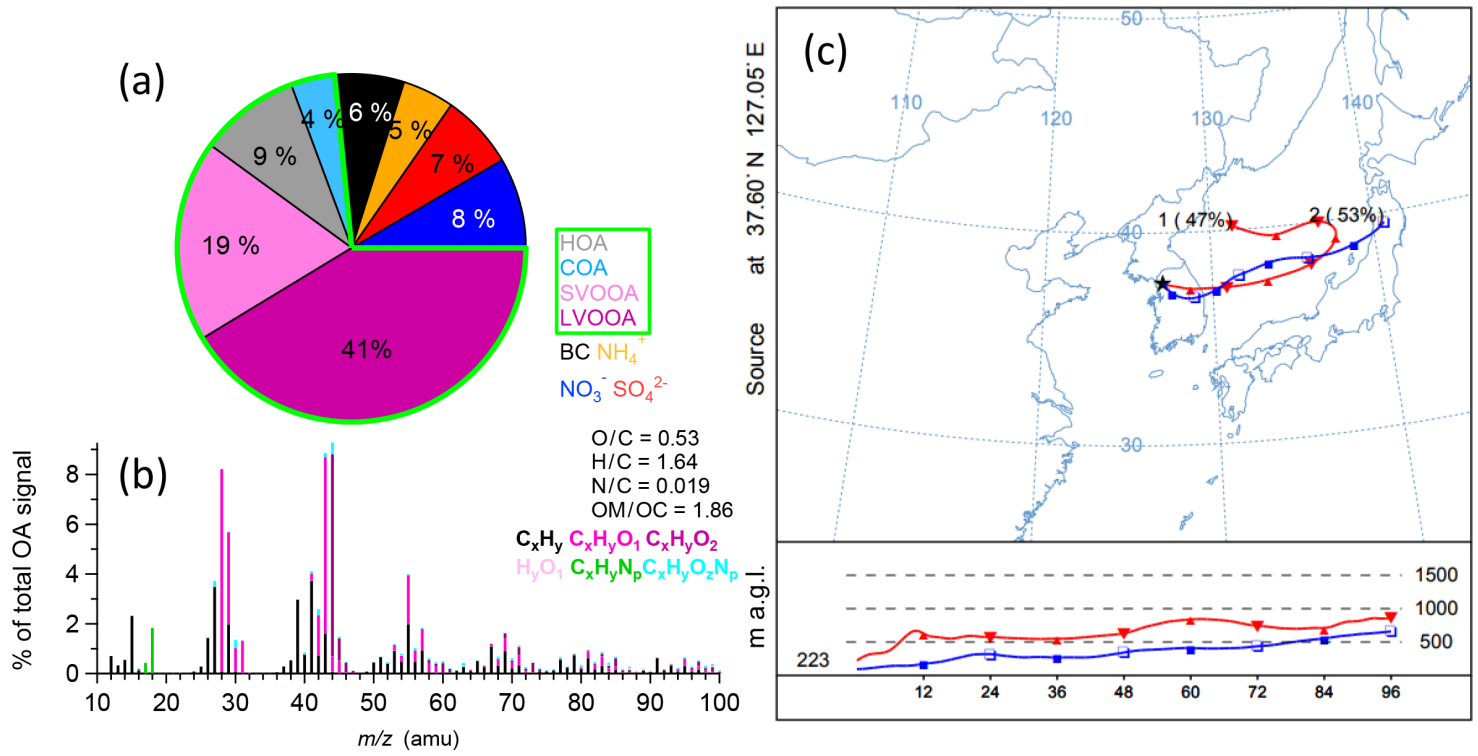

Figure 10. (a) Average compositional pie chart of $\mathrm{PM}_{1}$ species (non-refractory $\mathrm{PM}_{1}$ plus black carbon (BC)) and each of the $\mathrm{OA}$ factors over an organic-dominant period (20 May, 17:00-24 May, 00:00). The green outline indicates the fraction of total OA; and (b) the average high-resolution mass spectrum of OA colored by the different ion families. The average elemental ratios for the OA fraction are described (a); (c) two clusters of back-trajectories of air masses arriving at KIST during the organic-dominant period (20 May, 17:00-24 May, 00:00).

tants on a local scale were the main causes of wintertime haze episodes (Kim et al., 2017). However, the characteristics and the causes of haze episodes in the other seasons have not yet been investigated, although this information is required to better design reduction strategies for PM in SMA. To address this knowledge gap, in this section, the lifecycle of a major springtime haze episode in SMA is discussed.

Shorter haze episodes with daily average $\mathrm{PM}_{1}$ concentrations higher than $30 \mu \mathrm{g} \mathrm{m}^{-3}$ occurred several times during this study (Fig. 2). In addition, a severe haze episode lasted for 6 days from 26 to 31 May. Figure 11 presents a case study of the full cycle of this haze episode, which is classified into four stages: Stage 1 (S1, 24 May, 07:30-11:30) representing a clean period (precipitation) before the haze, Stage 2 (S2, 24 May, 11:30-26 May, 18:00) representing the formation stage of the haze, Stage 3 (S3, 26 May, 18:00-31 May, 24:00) representing the haze period with high concentrations of PM, and Stage 4 (S4, 1 June, 00:00-2 June, 24:00) representing the cleaning of haze. This classification was done mainly based on changes in atmospheric conditions, i.e., precipitation, wind direction and speed.

On 24 May, there was a short clean period (07:30 to 11:30; Period S1) when the average $\mathrm{PM}_{1}$ concentration was only $9 \mu \mathrm{g} \mathrm{m}^{-3}$ due to precipitation. PM concentration started to increase substantially after the rain stopped, and the increase was accompanied by a change in aerosol composition. During both Periods S1 and S2 (24 May, 11:30-26 May, 18:00), the predominant wind direction was southwest (Fig. 11b). Analyses of the MODIS images (Fig. S21), back-trajectories (Fig. S22) and meteorological conditions (Rapid Science
Synthesis Report, 2017) all indicated direct transports of air masses from the northwest, where large $\mathrm{SO}_{2}$ emission sources are located. The change in $\mathrm{PM}_{1}$ composition during Period S2 reflected the influence from such regional transport processes. For example, the mass fractions of species associated with regional sources, such as sulfate ( $28 \%$ during S2 vs. $20 \%$ during the entire period) and LV-OOA (18 vs. $15 \%$ ), increased (Fig. 11, Table S4), whereas the fractions of local pollutants such as SV-OOA (5 vs. $12 \%$ ), HOA (5 vs. $10 \%$ ), COA (5 vs. $7 \%$ ) and BC (4 vs. $7 \%$ ) decreased compared to the averaged $\mathrm{PM}_{1}$ composition during the entire period. In addition, the mass fraction of nitrate, one of the local secondary species, was also enhanced (20 vs. $17 \%$ ), and this was mainly due to the gas-particle partitioning of $\mathrm{HNO}_{3}$ and nighttime heterogeneous reactions in the nitrate formation facilitated by high RH $(78 \%)$ and low temperature $\left(18^{\circ} \mathrm{C}\right)(\mathrm{Ta}-$ ble S4). A good correlation $\left(r^{2}=0.48\right)$ between nitrate and $\mathrm{RH}$ corroborates the role of aqueous processes (Fig. S23).

During Period S3 (26 May, 18:00-31 May, 24:00), wind speed was reduced (Fig. 11, Table S4) and a more stagnant condition developed over the SMA. High mass loadings of submicron aerosol species persisted due to a lack of ventilation. In addition, similar to observations during a winter haze study at SMA (Kim et al., 2017), stagnant condition facilitated the accumulation of primary and secondary pollutants from local sources while limiting the transport of regional species. For example, the mass fractions of all the local pollutants in $\mathrm{PM}_{1}$ were enhanced during $\mathrm{S} 3$ compared to $\mathrm{S} 2$, e.g., $\mathrm{BC}(6 \%$ during S3 vs. $4 \%$ during S2), $\mathrm{HOA}$ ( $8 \%$ vs. $5 \%$ ), COA $(6 \%$ vs. $5 \%)$ and nitrate ( $22 \%$ vs. $20 \%)$, whereas the 

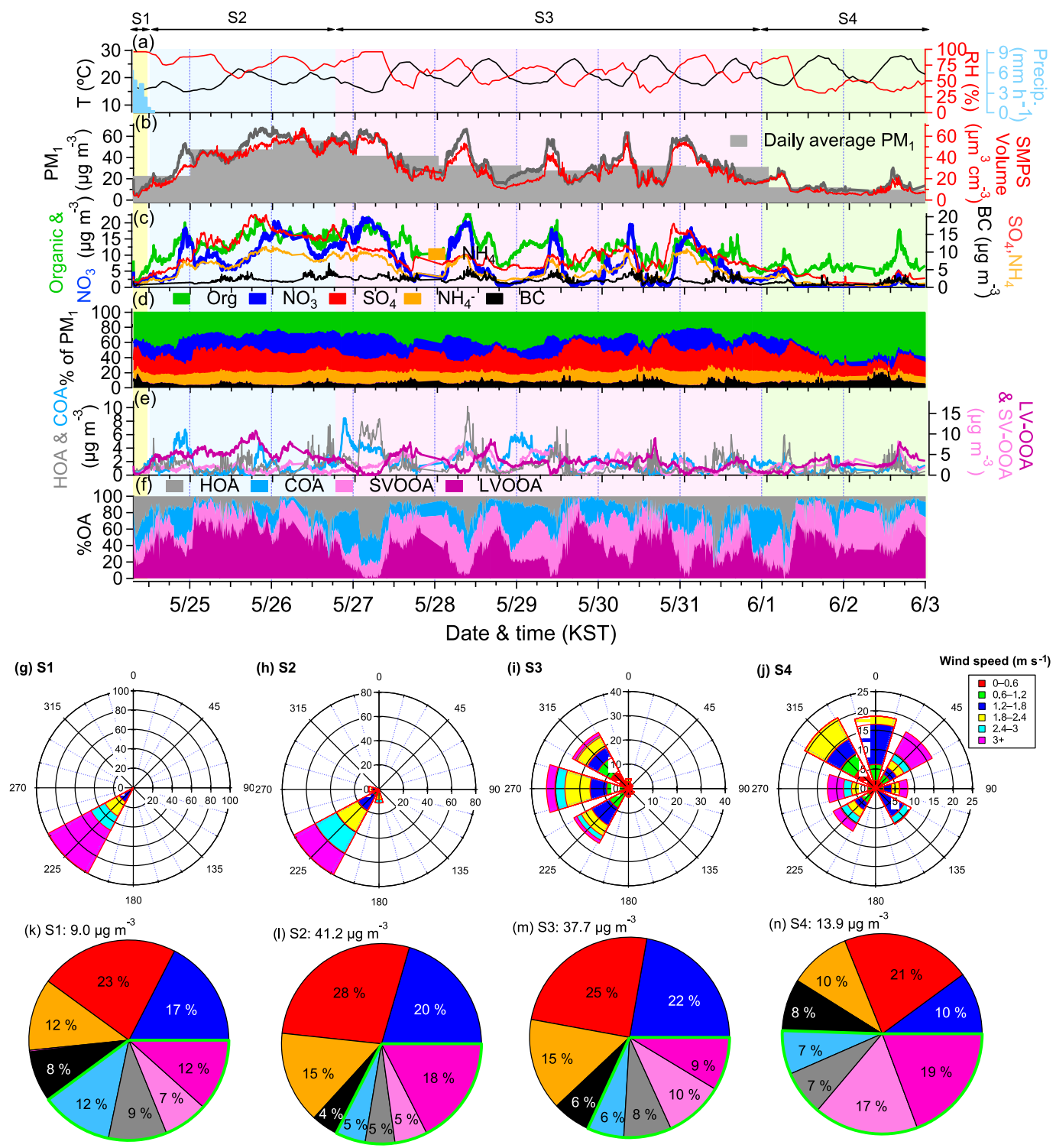

Figure 11. (a) Time series of ambient air temperature (T), relative humidity (RH), and precipitation (Precip.); (b) time series of total particulate matter $\left(\mathrm{PM}_{1}\right)$, scanning mobility particle sizer (SMPS) volume concentrations, and the $24 \mathrm{~h}$ averaged $\mathrm{PM}_{1}+\mathrm{BC}$ with bars; (c) time series of the organic (Org.), nitrate $\left(\mathrm{NO}_{3}^{-}\right)$, sulfate $\left(\mathrm{SO}_{4}^{2-}\right)$, ammonium $\left(\mathrm{NH}_{4}^{+}\right)$and $\mathrm{BC}$ aerosols; (d) time series of the mass fractional contribution of organic aerosols (Org.), nitrate $\left(\mathrm{NO}_{3}^{-}\right)$, sulfate $\left(\mathrm{SO}_{4}^{2-}\right)$, ammonium $\left(\mathrm{NH}_{4}^{+}\right)$, and $\mathrm{BC}$ to total $\mathrm{PM} \mathrm{M}_{1}$ concentration; (e) time series of each factor derived from the positive matrix factorization (PMF) analysis; (f) time series of mass fractional contribution of OA factors to OA; $(\mathbf{g}-\mathbf{j})$ wind rose plots, colored by wind speed; and (k-n) fractional contributions of each species to the total $\mathrm{PM}_{1}$ (non-refractory- $\mathrm{PM}_{1}$ plus $\mathrm{BC}$ ) mass for each stage in haze life.

fractions of regional species decreased, e.g., sulfate ( $25 \%$ vs. $28 \%$ ) and LV-OOA (9\% vs. $18 \%$ ).

From 1 to 2 June (Period S4), wind direction suddenly changed from westerly to north/northeasterly and average wind speed increased to $1.7 \mathrm{~m} \mathrm{~s}^{-1}$ (Table S4). This process cleaned out the atmosphere and reduced $\mathrm{PM}_{1}$ concentration to an average value of $14 \mu \mathrm{g} \mathrm{m}^{-3}$. OA was a major chemical species during this period, followed by sulfate and nitrate. During this time (S4), RH was low $(\sim 48 \%)$, which was less favorable for nighttime formation of nitrate. Furthermore, wind was predominantly from the north, whereas the main sources of $\mathrm{SO}_{2}$ and sulfate were located in the west, resulting in a low concentration of sulfate in SMA.

Overall, unlike the haze episodes observed in winter 2015 (Kim et al., 2017), which were mainly due to local influences under stagnant conditions, the spring haze events observed in this study occurred due to a combination of regional and local effects. A thorough understanding of the various haze 
scenarios and their underlying causes is required to better design air quality improvement strategies.

\section{Conclusions}

Aerosol composition, size distribution, sources, and evolution processes were investigated using an HR-ToF-AMS and an SMPS in SMA, Korea, during spring 2016 as a part of the KORUS-AQ campaign. The average $\mathrm{PM}_{1}$ concentration was $22.1 \mu \mathrm{g} \mathrm{m}^{-3}$ and the total mass was dominated by organics (44\%) and secondary inorganic species such as sulfate $(20 \%)$ and nitrate $(17 \%)$. Oxygenated organic aerosol and inorganic species (i.e., nitrate, sulfate, and ammonium) together accounted for $76 \%$ of the $\mathrm{PM}_{1}$ mass, thus indicating that aerosol pollution in SMA during springtime is influenced strongly by secondary aerosol formation.

Meteorological conditions and various emission sources influenced the concentrations, compositions, size distributions, and chemical composition of aerosol particles in SMA. Sulfate was found to be mainly associated with regional transport and to a lesser degree formed by aqueous-phase oxidation during nighttime. In contrast, nitrate was formed more locally due to intense urban emissions of $\mathrm{NO}_{x}$ coupled with elevated ozone concentrations and enhanced gas-toparticle partitioning during nighttime. Aqueous-phase processing under high humidity and lower temperature might have increased particulate nitrate concentrations occasionally as well. The two types of SOA showed significantly different features of diurnal patterns, which indicated that both were formed by photochemical reactions. However, SV-OOA represented freshly formed local SOA and was enhanced by gas-to-particle partition during nighttime, whereas LV-OOA usually increased in late afternoon, indicating that it is photochemically generated and regionally transported.

Based on detailed analyses of the haze periods in this study, we found that meteorological conditions played a significant role in controlling air quality in SMA. However, unlike in winter 2015, when haze episodes were found to occur mainly under stagnant conditions due to local influences, the springtime haze events occurred due to a combination of regional transport and local emissions. For example, a haze episode was found to begin with transport of plumes from upwind sources followed by stagnant conditions as well as meteorological conditions favorable for secondary aerosol formation. The sequential occurrence of plume transport and stagnant periods led to more severe air pollution that can last for several days. We also observed an episode dominated by OA started with the transport of plumes enriched in both $\mathrm{PM}_{1}$ and VOCs from the north and proceed under stagnant conditions with low mixing height. During this episode, inorganic aerosol formation was limited since the $\mathrm{SO}_{2}$ concentration was low and the meteorological condition was not favorable for nitrate aerosol formation (e.g., high temperature and low RH). However, due to high concentrations of VOCs and
$\mathrm{O}_{3}$, intense formation of SOA was observed. These results indicate that the high PM pollution in SMA during springtime was caused by a combination of factors, including local emissions, regional transport, and meteorological conditions which promote secondary aerosol formation or accumulation of pollutants. Therefore, understanding the haze episode is important for developing efficient mitigation to improve air quality.

Data availability. The hourly ambient temperature, RH, WS and WD data were acquired from the Korea meteorological administration (http://www.kma.go.kr). The hourly trace gas data (e.g., CO, $\mathrm{SO}_{2}, \mathrm{O}_{3}$ and $\mathrm{NO}_{2}$ concentrations) were acquired from the Korea Environment Corporation ( $K_{\text {eco }}$ ) (http://www.airkorea.or.kr) Raw data are archived at the Korea Institute of Science and Technology, and are available on request.

\section{The Supplement related to this article is available online at https://doi.org/10.5194/acp-18-7149-2018-supplement.}

Competing interests. The authors declare that they have no conflict of interest.

Acknowledgements. This work was supported by the Korea Institute of Science and Technology (KIST) and Basic Science Research Program through the National Research Foundation of Korea (NRF) funded by the Ministry of Science and ICT (2017R1A2B3004950). This research was also supported by the National Strategic Project-Fine Particle of the National Research Foundation of Korea (NRF) funded by the Ministry of Science and ICT (MSIT), the Ministry of Environment (ME), and the Ministry of Health and Welfare (MOHW) (2017M3D8A1092016). Qi Zhang acknowledges the Changjiang Scholars program of the Chinese Ministry of Education.

Edited by: Chak K. Chan

Reviewed by: three anonymous referees

\section{References}

Adhikary, B., Carmichael, G. R., Kulkarni, S., Wei, C., Tang, Y., D’Allura, A., Mena-Carrasco, M., Streets, D. G., Zhang, Q., Pierce, R. B., Al-Saadi, J. A., Emmons, L. K., Pfister, G. G., Avery, M. A., Barrick, J. D., Blake, D. R., Brune, W. H., Cohen, R. C., Dibb, J. E., Fried, A., Heikes, B. G., Huey, L. G., O'Sullivan, D. W., Sachse, G. W., Shetter, R. E., Singh, H. B., Campos, T. L., Cantrell, C. A., Flocke, F. M., Dunlea, E. J., Jimenez, J. L., Weinheimer, A. J., Crounse, J. D., Wennberg, P. O., Schauer, J. J., Stone, E. A., Jaffe, D. A., and Reidmiller, D. R.: A regional scale modeling analysis of aerosol and trace gas distributions 
over the eastern Pacific during the INTEX-B field campaign, Atmos. Chem. Phys., 10, 2091-2115, https://doi.org/10.5194/acp10-2091-2010, 2010.

Aiken, A. C., Decarlo, P. F., Kroll, J. H., Worsnop, D. R., Huffman, J. A., Docherty, K. S., Ulbrich, I. M., Mohr, C., Kimmel, J. R., Sueper, D., Sun, Y., Zhang, Q., Trimborn, A., Northway, M., Ziemann, P. J., Canagaratna, M. R., Onasch, T. B., Alfarra, M. R., Prevot, A. S. H., Dommen, J., Duplissy, J., Metzger, A., Baltensperger, U., and Jimenez, J. L.: $\mathrm{O} / \mathrm{C}$ and $\mathrm{OM} / \mathrm{OC}$ ratios of primary, secondary, and ambient organic aerosols with high-resolution time-of-flight aerosol mass spectrometry, Environ. Sci. Technol., 42, 4478-4485, https://doi.org/10.1021/es703009q, 2008.

Aiken, A. C., Salcedo, D., Cubison, M. J., Huffman, J. A., DeCarlo, P. F., Ulbrich, I. M., Docherty, K. S., Sueper, D., Kimmel, J. R., Worsnop, D. R., Trimborn, A., Northway, M., Stone, E. A., Schauer, J. J., Volkamer, R. M., Fortner, E., de Foy, B., Wang, J., Laskin, A., Shutthanandan, V., Zheng, J., Zhang, R., Gaffney, J., Marley, N. A., Paredes-Miranda, G., Arnott, W. P., Molina, L. T., Sosa, G., and Jimenez, J. L.: Mexico City aerosol analysis during MILAGRO using high resolution aerosol mass spectrometry at the urban supersite (T0) - Part 1: Fine particle composition and organic source apportionment, Atmos. Chem. Phys., 9, 6633-6653, https://doi.org/10.5194/acp-9-6633-2009, 2009.

Allan, J. D., Delia, A. E., Coe, H., Bower, K. N., Alfarra, M. R., Jimenez, J. L., Middlebrook, A. M., Drewnick, F., Onasch, T. B., Canagaratna, M. R., Jayne, J. T., and Worsnop, D. R.: A generalised method for the extraction of chemically resolved mass spectra from aerodyne aerosol mass spectrometer data, J. Aerosol. Sci., 35, 909-922, https://doi.org/10.1016/j.jaerosci.2004.02.007, 2004.

Allan, J. D., Williams, P. I., Morgan, W. T., Martin, C. L., Flynn, M. J., Lee, J., Nemitz, E., Phillips, G. J., Gallagher, M. W., and Coe, H.: Contributions from transport, solid fuel burning and cooking to primary organic aerosols in two UK cities, Atmos. Chem. Phys., 10, 647-668, https://doi.org/10.5194/acp-10-6472010, 2010.

Ban-Weiss, G. A., McLaughlin, J. P., Harley, R. A., Lunden, M. M., Kirchstetter, T. W., Kean, A. J., Strawa, A. W., Stevenson, E. D., and Kendall, G. R.: Long-term changes in emissions of nitrogen oxides and particulate matter from on-road gasoline and diesel vehicles, Atmos. Environ., 42, 220-232, https://doi.org/10.1016/j.atmosenv.2007.09.049, 2008.

Burkholder, J. B., Sander, S. P., Abbatt, J., Barker, J. R., Huie, R. E., Kolb, C. E., Kurylo, M. J., Orkin, V. L., Wilmouth, D. M., and Wine, P. H.: Chemical Kinetics and Photochemical Data for Use in Atmospheric Studies, Evaluation No. 18, JPL Publication 15-10, Jet Propulsion Laboratory, Pasadena, http://jpldataeval. jpl.nasa.gov (last access: 28 January 2018), 2015.

Canagaratna, M. R., Jayne, J. T., Jimenez, J. L., Allan, J. D., Alfarra, M. R., Zhang, Q., Onasch, T. B., Drewnick, F., Coe, H., Middlebrook, A., Delia, A., Williams, L. R., Trimborn, A. M., Northway, M. J., DeCarlo, P. F., Kolb, C. E., Davidovits, P., and Worsnop, D. R.: Chemical and microphysical characterization of ambient aerosols with the aerodyne aerosol mass spectrometer, Mass Spectrom. Rev., 26, 185-222, https://doi.org/10.1002/mas.20115, 2007.

Canagaratna, M. R., Jimenez, J. L., Kroll, J. H., Chen, Q., Kessler, S. H., Massoli, P., Hildebrandt Ruiz, L., Fortner, E., Williams, L.
R., Wilson, K. R., Surratt, J. D., Donahue, N. M., Jayne, J. T., and Worsnop, D. R.: Elemental ratio measurements of organic compounds using aerosol mass spectrometry: characterization, improved calibration, and implications, Atmos. Chem. Phys., 15, 253-272, https://doi.org/10.5194/acp-15-253-2015, 2015.

Cao, J.-J., Wang, Q.-Y., Chow, J. C., Watson, J. G., Tie, X.-X., Shen, Z.-X., Wang, P., and An, Z.-S.: Impacts of aerosol compositions on visibility impairment in Xi'an, China, Atmos. Environ., 59, 559-566, https://doi.org/10.1016/j.atmosenv.2012.05.036, 2012.

Cheng, Y., Zheng, G., Wei, C., Mu, Q., Zheng, B., Wang, Z., Gao, M., Zhang, Q., He, K., Carmichael, G., Pöschl, U., and Su, H.: Reactive nitrogen chemistry in aerosol water as a source of sulfate during haze events in China, Science Advances, 2, e1601530, https://doi.org/10.1126/sciadv.1601530, 2016.

Dall'Osto, M., Ovadnevaite, J., Ceburnis, D., Martin, D., Healy, R. M., O’Connor, I. P., Kourtchev, I., Sodeau, J. R., Wenger, J. C., and O'Dowd, C.: Characterization of urban aerosol in Cork city (Ireland) using aerosol mass spectrometry, Atmos. Chem. Phys., 13, 4997-5015, https://doi.org/10.5194/acp-134997-2013, 2013.

DeCarlo, P. F., Slowik, J. G., Worsnop, D. R., Davidovits, P., and Jimenez, J. L.: Particle morphology and density characterization by combined mobility and aerodynamic diameter measurements, Part 1: Theory, Aerosol Sci. Tech., 38, 1185-1205, https://doi.org/10.1080/02786820590928897, 2004.

DeCarlo, P. F., Kimmel, J. R., Trimborn, A., Northway, M. J., Jayne, J. T., Aiken, A. C., Gonin, M., Fuhrer, K., Horvath, T., Docherty, K. S., Worsnop, D. R., and Jimenez, J. L.: Field-deployable, high-resolution, time-of-flight aerosol mass spectrometer, Anal. Chem., 78, 8281-8289, https://doi.org/10.1021/ac061249n, 2006.

Draxler, R. R., Stunder, B., Rolph, G., Stein, A., and Taylor, A.: HYSPLIT_4 User's Guide, available at: http://www.arl.noaa. gov/documents/reports/hysplit_user_guide.pdf, NOAA Air Resources Laboratory, Silver Spring, Maryland, USA, 2012.

Draxler, R. R. and Hess, G. D.: Description of the HYSPLIT_4 modeling system, available at: http://www.arl.noaa.gov/ documents/reports/arl-224.pdf (last access: 5 January 2014), NOAA Air Resources Laboratory, Silver Spring, Maryland, USA, 1997.

Ge, X., Setyan, A., Sun, Y., and Zhang, Q.: Primary and secondary organic aerosols in Fresno, California during wintertime: Results from high resolution aerosol mass spectrometry, J. Geophys. Res.-Atmos., 117, D19301, https://doi.org/10.1029/2012jd018026, 2012.

Guo, S., Hu, M., Zamora, M. L., Peng, J., Shang, D., Zheng, J., Du, Z., Wu, Z., Shao, M., Zeng, L., Molina, M. J., and Zhang, R.: Elucidating severe urban haze formation in China, P. Natl. Acad. Sci. USA, 111, 17373-17378, https://doi.org/10.1073/pnas.1419604111, 2014.

Harrison, R. M. and Yin, J.: Particulate matter in the atmosphere: which particle properties are important for its effects on health?, Sci. Total Environ., 249, 85-101, https://doi.org/10.1016/S00489697(99)00513-6, 2000.

Hayes, P. L., Ortega, A. M., Cubison, M. J., Froyd, K. D., Zhao, Y., Cliff, S. S., Hu, W. W., Toohey, D. W., Flynn, J. H., Lefer, B. L., Grossberg, N., Alvarez, S., Rappenglueck, B., Taylor, J. W., Allan, J. D., Holloway, J. S., Gilman, J. B., Kuster, W. C., De Gouw, J. A., Massoli, P., Zhang, X., Liu, J., Weber, R. J., 
Corrigan, A. L., Russell, L. M., Isaacman, G., Worton, D. R., Kreisberg, N. M., Goldstein, A. H., Thalman, R., Waxman, E. M., Volkamer, R., Lin, Y. H., Surratt, J. D., Kleindienst, T. E., Offenberg, J. H., Dusanter, S., Griffith, S., Stevens, P. S., Brioude, J., Angevine, W. M., and Jimenez, J. L.: Organic aerosol composition and sources in Pasadena, California, during the 2010 CalNex campaign, J. Geophys. Res.-Atmos., 118, 9233-9257, https://doi.org/10.1002/jgrd.50530, 2013.

He, L. Y., Hu, M., Huang, X. F., Yu, B. D., Zhang, Y. H., and Liu, D. Q.: Measurement of emissions of fine particulate organic matter from Chinese cooking, Atmos. Environ., 38, 6557-6564, https://doi.org/10.1016/j.atmosenv.2004.08.034, 2004.

Heo, J. B., Hopke, P. K., and Yi, S. M.: Source apportionment of $\mathrm{PM}_{2.5}$ in Seoul, Korea, Atmos. Chem. Phys., 9, 4957-4971, https://doi.org/10.5194/acp-9-4957-2009, 2009.

Herndon, S. C., Onasch, T. B., Wood, E. C., Kroll, J. H., Canagaratna, M. R., Jayne, J. T., Zavala, M. A., Knighton, W. B., Mazzoleni, C., Dubey, M. K., Ulbrich, I. M., Jimenez, J. L., Seila, R., Gouw, J. A. D., Foy, B. D., Fast, J., Molina, L. T., Kolb, C. E., and Worsnop, D. R.: The correlation of secondary organic aerosol with odd oxygen in Mexico City, Geophys. Res. Lett., 35, L15804, https://doi.org/10.1029/2008GL034058, 2008.

Hu, W., Hu, M., Hu, W., Jimenez, J. L., Yuan, B., Chen, W., Wang, M., Wu, Y., Chen, C., Wang, Z., Peng, J., Zeng, L., and Shao, M.: Chemical composition, sources, and aging process of submicron aerosols in Beijing: Contrast between summer and winter, J. Geophys. Res.-Atmos., 121, 1955-1977, https://doi.org/10.1002/2015JD024020, 2016.

Huang, R.-J., Zhang, Y., Bozzetti, C., Ho, K.-F., Cao, J.-J., Han, Y., Daellenbach, K. R., Slowik, J. G., Platt, S. M., Canonaco, F., Zotter, P., Wolf, R., Pieber, S. M., Bruns, E. A., Crippa, M., Ciarelli, G., Piazzalunga, A., Schwikowski, M., Abbaszade, G., SchnelleKreis, J., Zimmermann, R., An, Z., Szidat, S., Baltensperger, U., El Haddad, I., and Prevot, A. S. H.: High secondary aerosol contribution to particulate pollution during haze events in China, Nature, 514, 218-222, https://doi.org/10.1038/nature13774, 2014.

Huang, X. F., He, L. Y., Hu, M., Canagaratna, M. R., Sun, Y., Zhang, Q., Zhu, T., Xue, L., Zeng, L. W., Liu, X. G., Zhang, Y. H., Jayne, J. T., Ng, N. L., and Worsnop, D. R.: Highly time-resolved chemical characterization of atmospheric submicron particles during 2008 Beijing Olympic Games using an Aerodyne HighResolution Aerosol Mass Spectrometer, Atmos. Chem. Phys., 10, 8933-8945, https://doi.org/10.5194/acp-10-8933-2010, 2010.

IPCC: Summary for policymakers, in: Climate Change 2013: The Physical Science Basis, Contribution of Working Group 1 to the Fifth Assessment Report of the Intergovernmental Panel on Climate Change, edited by: Stocker, T. F., Qin, D., Plattner, G.-K., Tignor, M., Allen, S. K., Boschung, J., Nauels, A., Xia, Y., Bex, V., and Midgley, P. M., Cambridge University Press, Cambridge, UK, New York, NY, USA, 3-29, 2013.

Jimenez, J. L., Jayne, J. T., Shi, Q., Kolb, C. E., Worsnop, D. R., Yourshaw, I., Seinfeld, J. H., Flagan, R. C., Zhang, X. F., Smith, K. A., Morris, J. W., and Davidovits, P.: Ambient aerosol sampling using the Aerodyne Aerosol Mass Spectrometer, J. Geophys. Res.-Atmos., 108, 447-457, https://doi.org/10.1029/2001jd001213, 2003.

Kaneyasu, N., Ohta, S., and Murao, N.: Seasonal variation in the chemical composition of atmospheric aerosols and gaseous species in SAPPORO, JAPAN, Atmos. Environ., 29, 1559-1568, https://doi.org/10.1016/1352-2310(94)00356-p, 1995.

Kim, E., Hopke, P. K., and Edgerton, E. S.: Source identification of Atlanta aerosol by positive matrix factorization, J. Air Waste Manage. Assoc., 53, 731-739, 2003.

Kim, H., Zhang, Q., Bae, G. N., Kim, J. Y., and Lee, S. B.: Sources and atmospheric processing of winter aerosols in Seoul, Korea: insights from real-time measurements using a high-resolution aerosol mass spectrometer, Atmos. Chem. Phys., 17, 2009-2033, https://doi.org/10.5194/acp-17-2009-2017, 2017.

Kim, S.-W., Choi, I.-J., and Yoon, S.-C.: A multi-year analysis of clear-sky aerosol optical properties and direct radiative forcing at Gosan, Korea (2001-2008), Atmos. Res., 95, 279-287, 2010.

Kim, Y., Kim, S.-W., Yoon, S.-C., Kim, M.-H., and Park, K.-H.: Aerosol properties and associated regional meteorology during winter pollution event at Gosan climate observatory, Korea, Atmos. Environ., 85, 9-17, https://doi.org/10.1016/j.atmosenv.2013.11.041, 2014.

KORUS-AQ mission whitepaper: https://espo.nasa.gov/home/ korus-aq (last access: 3 May 2018), 2015.

Kuwata, M., Zorn, S. R., and Martin, S. T.: Using Elemental Ratios to Predict the Density of Organic Material Composed of Carbon, Hydrogen, and Oxygen, Environ. Sci. Technol., 46, 787794, https://doi.org/10.1021/es202525q, 2012.

Middlebrook, A. M., Bahreini, R., Jimenez, J. L., and Canagaratna, M. R.: Evaluation of Composition-Dependent Collection Efficiencies for the Aerodyne Aerosol Mass Spectrometer using Field Data, Aerosol Sci. Tech., 46, 258-271, https://doi.org/10.1080/02786826.2011.620041, 2012.

Miyazaki, Y., Kondo, Y., Takegawa, N., Komazaki, Y., Fukuda, M., Kawamura, K., Mochida, M., Okuzawa, K., and Weber, R.: Time-resolved measurements of water-soluble organic carbon in Tokyo, J. Geophys. Res.-Atmos. (1984-2012), 111, D23206, https://doi.org/10.1029/2006JD007125, 2006.

Mohr, C., Huffman, J. A., Cubison, M. J., Aiken, A. C., Docherty, K. S., Kimmel, J. R., Ulbrich, I. M., Hannigan, M., and Jimenez, J. L.: Characterization of Primary Organic Aerosol Emissions from Meat Cooking, Trash Burning, and Motor Vehicles with High-Resolution Aerosol Mass Spectrometry and Comparison with Ambient and Chamber Observations, Environ. Sci. Technol., 43, 2443-2449, https://doi.org/10.1021/Es8011518, 2009.

Mohr, C., DeCarlo, P. F., Heringa, M. F., Chirico, R., Slowik, J. G., Richter, R., Reche, C., Alastuey, A., Querol, X., Seco, R., Penuelas, J., Jimenez, J. L., Crippa, M., Zimmermann, R., Baltensperger, U., and Prevot, A. S. H.: Identification and quantification of organic aerosol from cooking and other sources in Barcelona using aerosol mass spectrometer data, Atmos. Chem. Phys., 12, 1649-1665, https://doi.org/10.5194/acp-121649-2012, 2012.

Molina, M. J. and Molina, L.T.: Megacities and Atmospheric Pollution, J. Air Waste Manage. Assoc., 36, 644-680, 2004.

Paatero, P. and Tapper, U.: Positive matrix factorization a nonnegative factor model with optimal utilization of error estimates of data values, Environmetrics, 5, 111-126, https://doi.org/10.1002/env.3170050203, 1994.

PMF_Evaluation_Tool_Software: http://cires1.colorado.edu/ jimenez-group/wiki/index.php/PMF-AMS_Analysis_Guide\# PMF_Evaluation_Tool_Software (last access: 3 May 2018), 2017. 
Pope III, C. A. and Dockery, D. W.: Health Effects of Fine Particulate Air Pollution: Lines that Connect, J. Air Waste Manage. Assoc., 56, 709-742, 2006.

Pöschl, U.: Atmospheric Aerosols: Composition, Transformation, Climate and Health Effects, Angewandte Chemie International Edition, 44, 7520-7540, https://doi.org/10.1002/anie.200501122, 2005.

Prabhakar, G., Parworth, C. L., Zhang, X., Kim, H., Young, D. E., Beyersdorf, A. J., Ziemba, L. D., Nowak, J. B., Bertram, T. H., Faloona, I. C., Zhang, Q., and Cappa, C. D.: Observational assessment of the role of nocturnal residuallayer chemistry in determining daytime surface particulate nitrate concentrations, Atmos. Chem. Phys., 17, 14747-14770, https://doi.org/10.5194/acp-17-14747-2017, 2017.

Rapid Science Synthesis Report: https://www-air.larc.nasa.gov (last access: 3 May 2018), 2017.

Rao, Z., Chen, Z., Liang, H., Huang, L., and Huang, D.: Carbonyl compounds over urban Beijing: Concentrations on haze and nonhaze days and effects on radical chemistry, Atmos. Environ., 124, 207-216, https://doi.org/10.1016/j.atmosenv.2015.06.050, 2016.

Reyes-Villegas, E., Bannan, T., Le Breton, M., Mehra, A., Priestley, M., Percival, C., Coe, H., and Allan, J. D.: Online Chemical Characterization of Food-Cooking Organic Aerosols: Implications for Source Apportionment, Environ. Sci. Technol., 52, 5308-5318, https://doi.org/10.1021/acs.est.7b06278, 2018.

Seinfeld, J. H. and Pandis, S. N.: Atmospheric Chemistry and Physics: From Air Pollution to Climate Change, 2nd Edn., John Wiley \& Sons, New York, 1232 pp., 2006.

Setyan, A., Zhang, Q., Merkel, M., Knighton, W. B., Sun, Y., Song, C., Shilling, J. E., Onasch, T. B., Herndon, S. C., Worsnop, D. R., Fast, J. D., Zaveri, R. A., Berg, L. K., Wiedensohler, A., Flowers, B. A., Dubey, M. K., and Subramanian, R.: Characterization of submicron particles influenced by mixed biogenic and anthropogenic emissions using high-resolution aerosol mass spectrometry: results from CARES, Atmos. Chem. Phys., 12, 8131-8156, https://doi.org/10.5194/acp-12-8131-2012, 2012.

Sun, J., Zhang, Q., Canagaratna, M. R., Zhang, Y., Ng, N. L., Sun, Y., Jayne, J. T., Zhang, X., Zhang, X., and Worsnop, D. R.: Highly time- and size-resolved characterization of submicron aerosol particles in Beijing using an Aerodyne Aerosol Mass Spectrometer, Atmos. Environ., 44, 131-140, https://doi.org/10.1016/j.atmosenv.2009.03.020, 2010.

Sun, Y., Jiang, Q., Wang, Z., Fu, P., Li, J., Yang, T., and Yin, Y.: Investigation of the sources and evolution processes of severe haze pollution in Beijing in January 2013, J. Geophys. Res.-Atmos., 119, 4380-4398, https://doi.org/10.1002/2014jd021641, 2014.

Sun, Y., Jiang, Q., Xu, Y., Ma, Y., Zhang, Y., Liu, X., Li, W., Wang, F., Li, J., Wang, P., and Li, Z.: Aerosol characterization over the North China Plain: Haze life cycle and biomass burning impacts in summer, J. Geophys. Res.-Atmos., 121, 2508-2521, https://doi.org/10.1002/2015jd024261, 2016.

Sun, Y. L., Zhang, Q., Schwab, J. J., Demerjian, K. L., Chen, W. N., Bae, M. S., Hung, H. M., Hogrefe, O., Frank, B., Rattigan, O. V., and Lin, Y. C.: Characterization of the sources and processes of organic and inorganic aerosols in New York city with a high-resolution time-of-flight aerosol mass apectrometer, Atmos. Chem. Phys., 11, 1581-1602, https://doi.org/10.5194/acp11-1581-2011, 2011.
Sun, Y. L., Zhang, Q., Schwab, J. J., Yang, T., Ng, N. L., and Demerjian, K. L.: Factor analysis of combined organic and inorganic aerosol mass spectra from high resolution aerosol mass spectrometer measurements, Atmos. Chem. Phys., 12, 8537-8551, https://doi.org/10.5194/acp-12-8537-2012, 2012.

Sun, Y. L., Wang, Z. F., Fu, P. Q., Yang, T., Jiang, Q., Dong, H. B., Li, J., and Jia, J. J.: Aerosol composition, sources and processes during wintertime in Beijing, China, Atmos. Chem. Phys., 13, 4577-4592, https://doi.org/10.5194/acp-13-4577-2013, 2013.

Sun, Y. L., Du, W., Fu, P. Q., Wang, Q. Q., Li, J., Ge, X. L., Zhang, Q., Zhu, C. M., Ren, L. J., Xu, W. Q., Zhao, J., Han, T. T., Worsnop, D. R., and Wang, Z. F.: Primary and secondary aerosols in Beijing in winter: sources, variations and processes, Atmos. Chem. Phys., 16, 8309-8329, https://doi.org/10.5194/acp-168309-2016, 2016.

To, W. M., Yeung, L. L., and Chao, C. Y. H.: Characterisation of gas phase organic emissions from hot cooking oil in commercial kitchens, Indoor Built Environ., 9, 228-232, https://doi.org/10.1159/000057511, 2000.

ToF-AMS software downloads: http://cires.colorado.edu/ jimenez-group/ToFAMSResources/ToFSoftware/index.html (last access: 3 May 2018), 2017.

Ulbrich, I. M., Canagaratna, M. R., Zhang, Q., Worsnop, D. R., and Jimenez, J. L.: Interpretation of organic components from Positive Matrix Factorization of aerosol mass spectrometric data, Atmos. Chem. Phys., 9, 2891-2918, https://doi.org/10.5194/acp-92891-2009, 2009.

Wang, D., Zhou, B., Fu, Q., Zhao, Q., Zhang, Q., Chen, J., Yang, X., Duan, Y., and Li, J.: Intense secondary aerosol formation due to strong atmospheric photochemical reactions in summer: observations at a rural site in eastern Yangtze River Delta of China, Sci. Total Environ., 571, 1454-1466, https://doi.org/10.1016/j.scitotenv.2016.06.212, 2016a.

Wang, J., Ge, X., Chen, Y., Shen, Y., Zhang, Q., Sun, Y., Xu, J., Ge, S., Yu, H., and Chen, M.: Highly time-resolved urban aerosol characteristics during springtime in Yangtze River Delta, China: insights from soot particle aerosol mass spectrometry, Atmos. Chem. Phys., 16, 9109-9127, https://doi.org/10.5194/acp16-9109-2016, 2016b.

Wang, G., Kawamura, K., Lee, S., Ho, K., and Cao, J.: Molecular, Seasonal, and Spatial Distributions of Organic Aerosols from Fourteen Chinese Cities, Environ. Sci. Technol., 40, 4619-4625, 2006

Young, D. E., Allan, J. D., Williams, P. I., Green, D. C., Flynn, M. J., Harrison, R. M., Yin, J., Gallagher, M. W., and Coe, H.: Investigating the annual behaviour of submicron secondary inorganic and organic aerosols in London, Atmos. Chem. Phys., 15, 63516366, https://doi.org/10.5194/acp-15-6351-2015, 2015.

Young, D. E., Kim, H., Parworth, C., Zhou, S., Zhang, X., Cappa, C. D., Seco, R., Kim, S., and Zhang, Q.: Influences of emission sources and meteorology on aerosol chemistry in a polluted urban environment: results from DISCOVER-AQ California, Atmos. Chem. Phys., 16, 5427-5451, https://doi.org/10.5194/acp16-5427-2016, 2016.

Zhang, Q., Canagaratna, M. R., Jayne, J. T., Worsnop, D. R., and Jimenez, J. L.: Time- and size-resolved chemical composition of submicron particles in Pittsburgh: Implications for aerosol sources and processes, J. Geophys. Res.-Atmos., 110, D07S09, https://doi.org/10.1029/2004jd004649, 2005a. 
Zhang, Q., Worsnop, D. R., Canagaratna, M. R., and Jimenez, J. L.: Hydrocarbon-like and oxygenated organic aerosols in Pittsburgh: insights into sources and processes of organic aerosols, Atmos. Chem. Phys., 5, 3289-3311, https://doi.org/10.5194/acp-5-32892005, 2005b.

Zhang, Q., Jimenez, J. L., Canagaratna, M. R., Ulbrich, I. M., $\mathrm{Ng}, \mathrm{N}$. L., Worsnop, D. R., and Sun, Y.: Understanding atmospheric organic aerosols via factor analysis of aerosol mass spectrometry: a review, Anal. Bioanal. Chem., 401, 3045-3067, https://doi.org/10.1007/s00216-011-5355-y, 2011.

Zhang, Q. J., Beekmann, M., Freney, E., Sellegri, K., Pichon, J. M., Schwarzenboeck, A., Colomb, A., Bourrianne, T., Michoud, V., and Borbon, A.: Formation of secondary organic aerosol in the Paris pollution plume and its impact on surrounding regions, Atmos. Chem. Phys., 15, 13973-13992, https://doi.org/10.5194/acp-15-13973-2015, 2015.

Zhao, X., Wang, X., Ding, X., He, Q., Zhang, Z., Liu, T., Fu, X., Gao, B., Wang, Y., Zhang, Y., Deng, X., and Wu, D.: Compositions and sources of organic acids in fine particles $\left(\mathrm{PM}_{2.5}\right)$ over the Pearl River Delta region, south China, J. Environ. Sci. 26, 110-121, https://doi.org/10.1016/s1001-0742(13)60386$1,2014$.
Zhao, Y., Hu, M., Slanina, S., and Zhang, Y.: Chemical compositions of fine particulate organic matter emitted from Chinese cooking, Environ. Sci. Technol., 41, 99-105, https://doi.org/10.1021/es0614518, 2007.

Zheng, G. J., Duan, F. K., Su, H., Ma, Y. L., Cheng, Y., Zheng, B., Zhang, Q., Huang, T., Kimoto, T., Chang, D., Pöschl, U., Cheng, Y. F., and He, K. B.: Exploring the severe winter haze in Beijing: the impact of synoptic weather, regional transport and heterogeneous reactions, Atmos. Chem. Phys., 15, 2969-2983, https://doi.org/10.5194/acp-15-2969-2015, 2015.

Zheng, M., Wan, T. S. M., Fang, M., and Wang, F.: Characterization 1 of the non-volatile organic compounds in the aerosols of Hong Kong - Identification, abundance and origin, Atmos. Environ., 31, 227-237, https://doi.org/10.1016/1352-2310(96)001732, 1997.

Zhou, S., Collier, S., Jaffe, D. A., Briggs, N. L., Hee, J., Sedlacek III, A. J., Kleinman, L., Onasch, T. B., and Zhang, Q. Regional influence of wildfires on aerosol chemistry in the western US and insights into atmospheric aging of biomass burning organic aerosol, Atmos. Chem. Phys., 17, 2477-2493, https://doi.org/10.5194/acp-17-2477-2017, 2017. 